\title{
Timing of drought in the growing season and strong legacy effects determine the annual productivity of temperate grasses in a changing climate
}

\author{
Claudia Hahn ${ }^{1}$, Andreas Lüscher ${ }^{2}$, Sara Ernst-Hasler ${ }^{1}$, Matthias Suter ${ }^{2}$, and Ansgar Kahmen ${ }^{1}$ \\ ${ }^{1}$ Department of Environmental Sciences - Botany, University of Basel, Schönbeinstrasse 6, 4056 Basel, Switzerland \\ ${ }^{2}$ Forage Production and Grassland Systems, Agroscope, Reckenholzstrasse 191, 8046 Zurich, Switzerland
}

Correspondence: Claudia Hahn (claudia.hahn@unibas.ch) and Ansgar Kahmen (ansgar.kahmen@unibas.ch)

Received: 20 March 2020 - Discussion started: 24 April 2020

Revised: 1 December 2020 - Accepted: 4 December 2020 - Published: 27 January 2021

\begin{abstract}
The frequency of extreme weather events, such as droughts, is assumed to increase and lead to alterations in ecosystem productivity and thus the terrestrial carbon cycle. Although grasslands typically show reduced productivity in response to drought, the effects of drought on grassland productivity have been shown to vary strongly. Here we tested, in a 2-year field experiment, if the resistance and the recovery of grasses to drought varies throughout a growing season and if the timing of the drought influences droughtinduced reductions in annual aboveground net primary production (ANPP) of grasses. For the experiment we grew six temperate and perennial $\mathrm{C}_{3}$ grass species and cultivars in a field as pure stands. The grasses were cut six times during the growing season and subject to 10 week drought treatments that occurred either in the spring, the summer or the fall. Averaged across all grasses, drought-induced losses in productivity in spring were smaller $(-20 \%$ to $-51 \%)$ than in summer and fall ( $-77 \%$ to $-87 \%)$. This suggests a higher resistance to drought in spring when plants are in their reproductive stage and their productivity is the highest. After the release from drought, we found no prolonged suppression in growth. In contrast, post-drought growth rates of formerly drought-stressed swards outperformed the growth rates of the control swards. The strong overcompensation in growth after the drought release resulted in relatively small overall drought-induced losses in annual ANPP that ranged from $-4 \%$ to $-14 \%$ and were not affected by the timing of the drought event. In summary, our results show that (i) the resistance in growth rates of grasses to drought varies across the season and is increased during the reproductive pheno-
\end{abstract}

logical stage when growth rates are highest; (ii) that the positive legacy effects of drought indicate a high recovery potential of temperate grasses to drought; and (iii) that the high recovery can compensate for immediate drought effects on total annual biomass production to a significant extent.

\section{Introduction}

Numerous studies have attempted to quantify the effects of drought on grassland ecosystems in the past decade. In general, these studies have confirmed that a drought-induced water limitation typically leads to a reduction in net primary productivity (NPP; Fuchslueger et al., 2014, 2016; Gherardi and Sala, 2019; Wilcox et al., 2017; Wu et al., 2011). Importantly, however, these studies have also shown that the response of ecosystems to experimental drought can vary quite dramatically (Gherardi and Sala, 2019; Gilgen and Buchmann, 2009; Grant et al., 2014; Hoover et al., 2014; Wilcox et al., 2017). Among others, the drought response of grasslands has been shown to depend on the severity of the experienced drought (Vicca et al., 2012; Wilcox et al., 2017) and important secondary factors, such as the type of grassland affected (Byrne et al., 2013; Gherardi and Sala, 2019; Sala et al., 2015; Wilcox et al., 2017), the intensity of land use (Vogel et al., 2012; Walter et al., 2012), the plant functional composition (Gherardi and Sala, 2015; Hofer et al., 2016, 2017a; Mackie et al., 2018) or the biodiversity of an ecosystem (Haughey et al., 2018; Isbell et al., 2015; Kahmen et al., 2005; Wagg et al., 2017). These secondary factors that affect 
the responses of terrestrial ecosystems to drought are just beginning to be understood (Reichstein et al., 2013; Wu et al., 2011). Defining their impact on the drought response of terrestrial ecosystems is essential for quantitative predictions of drought effects on the carbon cycle and for the ultimate inclusion of the drought responses of terrestrial ecosystems in coupled land-surface models (Paschalis et al., 2020; Schiermeier, 2010; Smith et al., 2014).

Grassland ecosystems often show a pronounced seasonality, where plants undergo different phenological, physiological, morphological or ontogenetic stages throughout a year (Gibson, 2009; Voigtländer and Boeker, 1987). Temperate European grasslands, for example, are highly productive early in the growing season during reproductive growth, while they show much lower growth rates during vegetative stages in summer and fall (Menzi et al., 1991; Voisin, 1988). Several studies have addressed how the seasonal timing of drought affects the aboveground net primary productivity (ANPP) of North American $\mathrm{C}_{4}$ grasslands (Nippert et al., 2006; Petrie et al., 2018). It has been suggested that moisture availability during the stalk production of the dominant $\mathrm{C}_{4}$ grass species in midsummer is particularly important for maintaining the annual productivity of these grasslands (Denton et al., 2017; La Pierre et al., 2011). For $\mathrm{C}_{3}$ dominated temperate grasslands, this would imply that spring, when grasses flower and have the highest growth rates, is the time when the productivity should be the most susceptible to drought and that productivity should be less prone to drought-induced losses in the summer and fall. Empirical evidence of how the seasonal timing of a drought event affects the productivity of temperate $\mathrm{C}_{3}$ dominated grasslands is, however, missing.

The impact of drought on the annual ANPP of ecosystems depends on the immediate effects of drought on productivity (determined by the drought resistance of the ecosystem), but also on potential legacy effects that occur after drought release (determined by the drought recovery of the ecosystem; Sala et al., 2012; Seastedt and Knapp, 1993). In particular, legacy effects of drought are a critical yet rarely explored component that can strongly affect the impact of drought on the annual ANPP of an ecosystem (Finn et al., 2018; Ingrisch and Bahn, 2018; Petrie et al., 2018; Sala et al., 2012). Previously, it was believed that the drought history (e.g., previous year's annual precipitation deficit) of an ecosystem is crucial for the annual ANPP and that the magnitude of the drought history negatively influences the current ANPP (Mackie et al., 2018; Reichmann et al., 2013; Sala et al., 2012; Yahdjian and Sala, 2006). In contrast, there is now increasing evidence that drought-stressed plants or ecosystems can respond to drought release with an overcompensation of their physiological activity or growth (GriffinNolan et al., 2018; Hofer et al., 2017a; Shen et al., 2016). Following an experimental drought, tropical and temperate tree seedlings have, for example, exhibited higher net photosynthesis rates than seedlings that had not experienced a drought event (Hagedorn et al., 2016; O'Brien et al., 2017). In grasslands, Hofer et al. (2016) have recently shown that formerly drought-stressed swards had a higher productivity in the post-drought period than non-stressed control swards. Other studies have shown that the species richness of a grassland contributes to this effect (Kreyling et al., 2017; Wagg et al., 2017). Even across growing seasons, it has been suggested that the previous growing season precipitation patterns can have positive legacy effects on the current year's productivity in the ecosystems (Shen et al., 2016). As legacy effects can either worsen or diminish immediate drought effects on annual ANPP, their assessment is essential for determining if the sensitivity of annual ANPP to the timing of drought is driven by the resistance or the recovery of the system (Petrie et al., 2018; Shen et al., 2016). This requires, however, a detailed analysis of not only annual ANPP, but also the assessment of biomass increase (i.e., productivity) during and after the release of a drought event.

In the work that we present here, we experimentally assessed if the drought response of the annual ANPP (i.e., the productivity of the standing aboveground biomass) of six different grass species and cultivars that are common in temperate $\mathrm{C}_{3}$ grasslands depends on the timing of the drought event in the growing season. To do so, we determined the drought resistance and recovery for these grasses at different times of the growing season. Specifically, we tested the following:

(i) if the timing of a drought event within the growing season (e.g., spring, summer and fall) has an effect on the immediate aboveground productivity reduction - i.e., the resistance of an ecosystem,

(ii) if the timing of a drought event within the growing season affects the recovery of an ecosystem, and

(iii) how the combination of resistance and recovery at different times of the growing season impacts the annual ANPP of drought-stressed $\mathrm{C}_{3}$ grasses.

\section{Materials and methods}

\subsection{Research site}

The experiment was performed in the years 2014 and 2015 near Zurich, Switzerland $\left(47^{\circ} 26^{\prime} \mathrm{N}, 8^{\circ} 31^{\prime} \mathrm{E}\right.$; altitude $-490 \mathrm{~m}$ above sea level (a.s.1.); mean annual temperature $-9.4^{\circ} \mathrm{C}$; mean annual precipitation - $1031 \mathrm{~mm}$ ), on an Eutric Cambisol soil. For the experiment, we established four perennial $\mathrm{C}_{3}$ grass species, two of them in two cultivars, all of which are commonly used in agricultural practice, in August 2013 on 96 plots $(3 \mathrm{~m} \times 5 \mathrm{~m})$. The grasses were sown as pure stands on a highly productive field that yields typically around $12 \mathrm{t}$ grass dry matter per year and hectare (i.e., $1200 \mathrm{~g} \mathrm{~m}^{-2}$ ). The establishment followed the basic procedures of sowing permanent highly productive grasslands, 

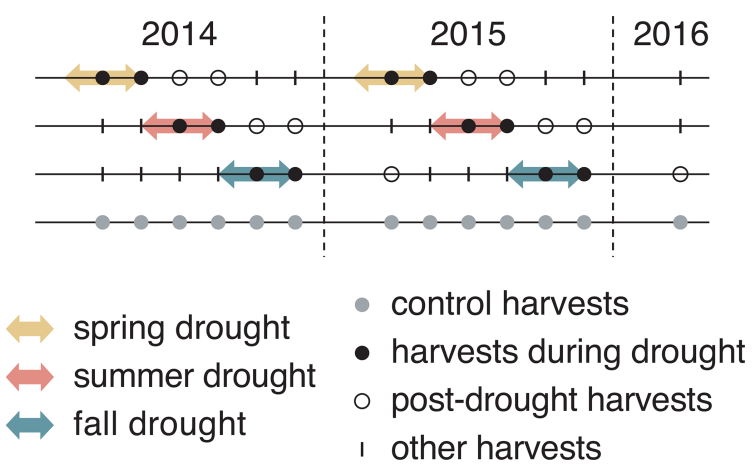

Figure 1. Experimental design of the experiment that lasted for 2 consecutive years (2014 and 2015), with six evenly distributed harvests in both years and one additional harvest at the beginning of 2016. Arrows indicate the duration of each drought treatment (10 weeks). Each treatment was replicated four times for each of six grass species and cultivars.

where before sowing, the existing vegetation at the site (which was winter wheat) was plowed. The grasses were established in the growing season before the experiment started, following best practice which guaranteed the full establishment of the swards (including vernalization during winter) and full productivity in the following year. The six grasses were Lolium perenne L. early flowering (LPe; cultivar Artesia), Lolium perenne L. late flowering (LPl; cultivar Elgon), Dactylis glomerata L. early flowering (DGe; cultivar Barexcel), Dactylis glomerata L. late flowering (DGl; cultivar Beluga), Lolium multiflorum Lam. var italicum Beck (LM; cultivar Midas) and Poa pratensis L. (PP; cultivar Lato). Phosphorous, potassium and manganese were applied, following national Swiss fertilization recommendations for intensely managed grasslands, at the beginning of each growing season ( $39 \mathrm{~kg} \mathrm{Pha}^{-1}, 228 \mathrm{~kg} \mathrm{Kha}^{-1}$ and $35 \mathrm{~kg} \mathrm{Mg} \mathrm{ha}^{-1}$ ). In addition, all plots received the same amount of mineral $\mathrm{N}$ fertilizer as ammonium nitrate $\left(280 \mathrm{~kg} \mathrm{Nha}^{-1}\right.$, divided into six applications per year). The solid $\mathrm{N}$ fertilizer was applied at the beginning of the growing season $\left(80 \mathrm{~kg} \mathrm{Nha}^{-1}\right)$ and after each of the first five cuts ( $40 \mathrm{~kg} \mathrm{Nha}^{-1}$ each time).

\subsection{Experimental design}

Each of the six grass species (different species and cultivars) was subject to four treatments, namely one rain-fed control and three seasonal drought treatments (spring, summer and fall; see Fig. 1). We used a randomized complete block design, with four blocks representing the four replicates. Each block contained all 24 plots (six species times four treatments), which were fully randomized. A drought treatment lasted for 10 weeks. Drought was simulated using rain-out shelters that excluded rainfall completely from the treatment plots. The rain-out shelters were tunnel shaped and consisted of steel frames $(3 \mathrm{~m} \times 5.5 \mathrm{~m}$; height $-140 \mathrm{~cm})$ that were covered with transparent and UV-radiation-transmissible green- house foil (Lumisol Clear; 200 my; Hortuna AG, Winikon, Switzerland). To allow air circulation, shelters were open on both opposing short ends and had ventilation openings of $35 \mathrm{~cm}$ height over the entire length at the top and the bottom of both long sides. Gutters were installed to prevent the water from flowing onto adjacent plots, and a $0.75 \mathrm{~m}$ border zone at each plot was not considered for measurements to prevent the possible effect of lateral water flow in the soil. These shelters and plot design had previously been successfully used in other grassland drought experiments (Hofer et al., 2016, 2017a, b). Rain-fed controls were subject to the natural precipitation regime. However, when soil water potential $\left(\Psi_{\text {Soil }}\right)$ sank below $-0.5 \mathrm{MPa}$ due to naturally dry conditions, control plots were additionally watered with $20 \mathrm{~mm}$ of water (300 L per plot). In summer 2014, the irrigation was delayed by approximately 1 week due to organizational difficulties, leading to a further decrease in $\Psi_{\text {Soil }}$ until irrigation could start. Watering happened once on 16 and 17 June 2014 and three times in 2015 ( 7 and 14 July and 11 August).

\subsection{Environmental measurements}

Relative humidity and air temperature were measured hourly at the field site using VP-3 humidity, temperature and vapor pressure sensors (Decagon Devices, Inc., Pullman, WA, USA). Measurements were conducted at control and treatment plots under the rain-out shelters $(n=2)$. Information on precipitation and evapotranspiration was provided by the national meteorological service stations (MeteoSwiss) that were in close proximity to our research site (the average of the two surrounding meteorological stations Zurich Affoltern, at a $1.4 \mathrm{~km}$ distance, and Zurich Kloten, at a $4.5 \mathrm{~km}$ distance). $\Psi_{\text {Soil }}$ was measured at a $10 \mathrm{~cm}$ depth on an hourly basis using 32 MPS-2 dielectric water potential sensors (Decagon Devices, Inc., Pullman, WA, USA). The 32 soil water potential sensors were evenly distributed over the field and treatments. Daily means of all measurements were calculated per treatment but across grasses, since no grass-specific alterations in $\Psi_{\text {Soil }}$ were expected (Hoekstra et al., 2014) or measured $(n=8)$.

\subsection{Harvests}

Aboveground biomass was harvested six times per year, in 5-week intervals in 2014 and 2015, resulting in six growth periods per year (see Fig. 1). Aboveground biomass was also harvested once in spring 2016. Such a high frequency of harvests is typical for highly productive European grasslands used for fodder production. For the purpose of our study, this high-resolution biomass sampling allows the analyses of the immediate drought effects and the impacts of drought that occur after the release from drought on productivity. The harvests were synchronized with the drought treatments and occurred 5 and 10 weeks after the installation of the shelters on a respective treatment. For the harvest, aboveground biomass 
was cut at $7 \mathrm{~cm}$ height above the ground and harvested from a central strip $(5 \mathrm{~m} \times 1.5 \mathrm{~m})$ of the plot $(5 \mathrm{~m} \times 3 \mathrm{~m})$ using an experimental plot harvester (Hege 212; Wintersteiger AG, Ried im Innkreis, Austria). The fresh weight of the total harvest of a plot was determined with an integrated balance directly on the plot harvester. Dry biomass production was determined by assessing the dry weight-fresh weight ratios of the harvested biomass. For this, a biomass subsample was collected for each plot, and the fresh and dry weight (dried at $60^{\circ} \mathrm{C}$ for $48 \mathrm{~h}$ ) was determined. After the harvest of the aboveground biomass in the central strip of a plot, the remaining standing biomass in a plot was mowed $7 \mathrm{~cm}$ above ground level (a.g.l.) and removed.

\subsection{Roots}

Belowground biomass of four grasses (DGe, DGl, LPe and LPl) was harvested six times per year. For each treatment, samples were collected at the end of a drought treatment and 6 to 8 weeks after drought release from the respective treatment and control plots. Samples were collected using a manual soil auger with a diameter of $7 \mathrm{~cm}$. For each plot, samples of the upper $14 \mathrm{~cm}$ soil were taken from two different locations within a plot (one sample directly from a tussock and one from in between tussocks) and pooled as one sample per plot. All samples were washed using a sieve with a mesh size of $0.5 \mathrm{~cm} \times 0.5 \mathrm{~cm}$ and weighed after drying (at $60^{\circ} \mathrm{C}$ for $72 \mathrm{~h})$.

\subsection{Determining drought impacts on productivity}

In order to allow the comparison of grassland productivity in the different treatments across the 2 years, we standardized the productivity that occurred in between the two harvests (i.e., during 5 weeks) for growth-related temperature effects and calculated temperature-weighted growth rates for each of the six grasses $\left(\mathrm{DMYT}_{\text {sum }}\right.$; see Menzi et al., 1991). For this purpose, we determined the temperature sums of daily mean air temperature (as measured in the treatment and control plots) above a baseline temperature of $5^{\circ} \mathrm{C}\left(T_{\text {sum }}\right)$ for each growth period (i.e., 5 weeks prior to harvest). Dry matter yield (DMY) of a given harvest was then divided by the temperature sum of the corresponding time period to obtain temperature-weighted growth rates (henceforth simply referred to as growth rate) as follows:

$\operatorname{DMYT}_{\text {sum }}=\operatorname{DMY}\left(\mathrm{g} \mathrm{m}^{-2}\right) / T_{\text {sum }}\left({ }^{\circ} \mathrm{C}\right)$.

To determine the absolute change in growth (ACG) of a drought treatment on aboveground growth rate, we calculated the difference between temperature-weighted growth rates in a drought treatment (drt) and the corresponding control (ctr) as follows:

$\mathrm{ACG}=\mathrm{DMYT}_{\text {sum }}(\mathrm{drt})-\mathrm{DMYT}_{\text {sum }}(\mathrm{ctr})$.
To determine the relative change in growth (RCG) due to drought, we calculated the percentage change of temperature-weighted growth rates as follows:

$\mathrm{RCG}=100 \cdot\left(\mathrm{DMYT}_{\text {sum }}(\mathrm{drt}) / \mathrm{DMYT}_{\text {sum }}(\mathrm{ctr})-1\right)$.

Annual ANPP as an average of the different grasses was determined by adding up the dry matter yields of the six harvests of a growing season. These data were not temperaturecorrected dry matter yield (DMY).

\subsection{Data analysis}

Relative and absolute changes in DMYT sum due to drought, the season of drought and the tested grasses were analyzed using linear mixed-effects models (Pinheiro and Bates, 2000). Temperature-weighted growth rate $\left(\mathrm{DMYT}_{\text {sum }}\right)$ was regressed on the fixed variables season (factor of three levels - spring, summer and fall), drought (factor of two levels - control and drought treatment) and grass (factor of six levels - LPe, LPl, DGe, DGl, LM and PP), including all interactions. To account for repeated measurements of the control plots over time (as the control for every seasonal drought treatment was the same), the plot was specified as a random factor, thereby accounting for a potential correlation of $\mathrm{DMYT}_{\text {sum }}$ over time. DMYT $\mathrm{D}_{\text {sum }}$ was naturally $\log$ transformed prior to the analysis to improve homogeneity and normal distribution of the residual variance. This transformation also implies that the regressions provide the inference to relative changes in $\mathrm{DMYT}_{\text {sum }}$, namely RCG. A temporal compound symmetry correlation structure was initially imposed on the residuals, yet it turned out that the estimated correlation parameter was very small. A likelihood ratio test indicated its non-significance $(p>0.5)$, and it was finally omitted. However, an inspection of residuals revealed clear differences in their variance among seasons and control and drought plots, and the residual variance parameter was defined as $\operatorname{Var}\left(e_{j k}\right)=\sigma^{2} \delta_{j k}^{2}$, with $\delta$ being a ratio to represent $j \times k$ variances - one for each of the three seasons $j$ under control and drought conditions $k$ (Pinheiro and Bates, 2000). The marginal and conditional $R^{2}$ of the model was calculated following Nakagawa and Schielzeth (2013). This model was applied to DMYT $\mathrm{Dum}_{\text {sum }}$ at each second growth period under drought and the second post-drought growth period in 2014 and 2015. Finally, absolute changes in DMYT ${ }_{\text {sum }}$ are displayed in Fig. $4 \mathrm{~b}$ to improve the interpretation of the data.

Root dry weight was analyzed in a similar way, i.e., it was naturally $\log$ transformed prior to analyses, and the same explanatory factors were applied in a mixed model, except that the factor of grass had only four levels (only LPe, LPl, DGe and DGl were measured). Here, the estimation of a single residual variance parameter $e_{i}$ was sufficient to fulfill the model assumptions. This model was applied to root dry weight harvested in 2014 at the end of each drought treatment and 6 to 8 weeks after drought release. Absolute changes in root dry weight are displayed in Fig. 6b without further tests. 
Annual ANPP was analyzed by a two-way analysis of variance (ANOVA). The first factor of season treatment consisted of four levels, namely control, spring drought, summer drought and fall drought. The second factor, grass, consisted of six levels that represented the six grasses. This ANOVA was performed for each of the years 2014 and 2015.

All statistical analyses were done using the statistical software R, version 3.5.1 (R Foundation for Statistical Computing, Vienna, Austria, 2018). Mixed-effects models were fitted using the package nlme, version 3.1-137, (Pinheiro and Bates, 2000), and graphics were implemented with the package ggplot2, version 2.1.0 (Wickham, 2016).

\section{Results}

\subsection{Precipitation, evapotranspiration and soil water potential}

The 2 investigated years differed in their weather conditions. The difference in annual rainfall between the 2 years was 937.1 and $801.9 \mathrm{~mm}$ for 2014 and 2015, respectively (see Table 1). Considering only the growing season, the year 2015 was exceptionally dry, while 2014 showed normal weather conditions for the experimental site. This was particularly during the fourth, fifth and sixth regrowth period (second half of the growing season), where water input (rainfall plus irrigation, the latter being $0 \mathrm{~mm}$ in 2014 and $60 \mathrm{~mm}$ in 2015) was $405.5 \mathrm{~mm}$ for 2014 and $213.7 \mathrm{~mm}$ for 2015 (Fig. 1), while evapotranspiration was 142.9 and $258.1 \mathrm{~mm}$ for 2014 and 2015, respectively (Fig. 1). For the unsheltered control plots, this resulted in an ecosystem water balance for that time of $262.6 \mathrm{~mm}$ in 2014 and only $-44.4 \mathrm{~mm}$ in 2015 . For all the other plots, the values of 2015 were even more extreme as they did not receive the $60 \mathrm{~mm}$ irrigation. The shelter periods reduced the total annual precipitation in the different treatments between $-17.9 \%$ and $-37.0 \%$ and the precipitation of the growing season (duration of the experiment - approx. March-November) by between $-23.1 \%$ and $-45.8 \%$ (see Table 1).

In $2014, \Psi_{\text {Soil }}$ was severely reduced in the drought treatments and reached values around the permanent wilting point $(-1.5 \mathrm{MPa})$ for the entire second half of the sheltered periods in all treatments (spring, summer and fall; Fig. 2b-e; Table 2). Due to low rainfall in June 2014, $\Psi_{\text {Soil }}$ dropped not only in the sheltered summer drought treatment but also in the control and the fall drought treatment (that was not yet sheltered). $\Psi_{\text {Soil }}$ recovered in the treatment plots after each sheltered period and reached $\Psi_{\text {Soil }}$ values comparable to the ones in the control plots. Because of the lack of rain in June 2014, the full rewetting of the spring drought treatment occurred only in the second post-drought growth period after the spring drought shelter period, while after the summer drought treatment rewetting occurred in the first post-drought growth period.
In 2015 , drought treatments reduced $\Psi_{\text {Soil }}$ in all seasons (Fig. 2g-k). However, an intense rain event caused some surface runoff in the field on 1 May 2015, which partly interrupted the spring drought treatment. Still, for the second growth period of the spring drought treatment of 2015, the median of $\Psi_{\text {Soil }}$ was at $-0.77 \mathrm{MPa}$ - a value comparable to that of the second growth period of the summer drought treatment $\left(-0.83 \mathrm{MPa}\right.$; Table 2). In 2015, $\Psi_{\text {Soil }}$ reached lower values during the shelter period in the fall treatment than during the shelter period in the spring and summer treatments. Due to a lack of rain in $2015, \Psi_{\text {Soil }}$ values recovered only partly after the end of the shelter period in the spring and summer drought treatments and remained significantly below that of the control plots for both post-drought growth periods (Table 2).

Daily mean air temperature under the rain-out shelters was 0.7 and $0.6^{\circ} \mathrm{C}$ higher in 2014 and 2015 , respectively, compared to the control plots (Table 2).

\subsection{Varying growth rates throughout the growing season}

The temperature-weighted growth rates of the six investigated grass species and cultivars in the control plots showed a very strong seasonal pattern (Fig. 3a). In both years, it was highest during the second growth period in spring and sharply declined to values that were 2 to 8 times smaller in summer and fall. In summer and autumn 2015, growth rates of the grasses were clearly lower than in 2014. Root biomass increased towards summer and slightly decreased after summer in 2014 (Fig. 3b, Table A1 in Appendix; season $p<0.001)$.

\subsection{Seasonality of drought resistance}

The growth rates of the six grass species and cultivars were barely affected by the exclusion of rain during the first 5 weeks of sheltering (Fig. 4). However, during the second sheltered growth period (drought weeks 6 to 10), the drought treatments strongly reduced temperature-weighted growth rates in all seasons, in both years, and in relative and absolute terms (Figs. 4 and 5; Table 3). In both years, averaged over all six grasses, the relative drought-induced changes in growth rates compared to the controls were smallest in spring (2014 $--51 \% ; 2015--20 \%)$ and clearly larger in summer (2014 $--81 \% ; 2015--85 \%)$ and fall $(2014--77 \% ; 2015-$ $-84 \%$; Fig. 4a; Table 3; season $\times$ treatment $p<0.001$ ). As such, the drought resistance of temperate grasses throughout the growing season was largest in spring when their growth rates in the control were especially high (Fig. 3a; second regrowth). This pattern was generally observed for all six grass species and cultivars tested (Fig. 5a), even though there was a significant season $\times$ treatment $\times$ grass interaction (Table 3 ). In 2014, this interaction mainly was derived from DGl and PP, showing an exceptionally large drought-induced growth 
Table 1. Amount of precipitation that has fallen in the 2 years of the experiment, and the amount of excluded precipitation during the sheltered drought periods in the years 2014 and 2015. Growing season precipitation refers to the time period between the first setup of the shelters in spring and the last harvest of each year.

\begin{tabular}{|c|c|c|c|c|}
\hline \multicolumn{5}{|c|}{2014} \\
\hline \multirow[t]{2}{*}{$\begin{array}{l}\text { Annual precipitation } \\
(\mathrm{mm})\end{array}$} & $\begin{array}{l}\text { Growing season precipitation } \\
(\mathrm{mm})\end{array}$ & Spring & Summer & Fall \\
\hline & & \multicolumn{3}{|c|}{ Excluded precipitation (mm) } \\
\hline \multirow[t]{5}{*}{937.1} & 634.4 & 167.4 & 249.3 & 211.7 \\
\hline & & \multicolumn{3}{|c|}{ Excluded precipitation annually $(\%)$} \\
\hline & & 17.9 & 26.6 & 22.5 \\
\hline & & \multicolumn{3}{|c|}{ Excluded precipitation in growing season $(\%)$} \\
\hline & & 26.4 & 39.3 & 33.4 \\
\hline \multicolumn{5}{|c|}{2015} \\
\hline \multirow[t]{2}{*}{$\begin{array}{l}\text { Annual precipitation } \\
(\mathrm{mm})\end{array}$} & $\begin{array}{l}\text { Growing season precipitation } \\
(\mathrm{mm})\end{array}$ & Spring & Summer & Fall \\
\hline & & \multicolumn{3}{|c|}{ Excluded precipitation (mm) } \\
\hline \multirow[t]{5}{*}{801.9} & 568.6 & 296.9 & 144.7 & 116.9 \\
\hline & & \multicolumn{3}{|c|}{ Excluded precipitation annually (\%) } \\
\hline & & 37.0 & 18.0 & 14.6 \\
\hline & & \multicolumn{3}{|c|}{ Excluded precipitation in growing season $(\%)$} \\
\hline & & 52.2 & 25.4 & 20.6 \\
\hline
\end{tabular}

reduction in fall. In 2015, it was explained by an especially low drought response of DGl in spring and strong responses of DGl in summer and LPe and PP in fall (Fig. 5a).

In 2014, the absolute drought-induced reduction in growth across all six grass species and cultivars was largest in spring $\left(-0.5 \mathrm{~g} \mathrm{~m}^{-2}{ }^{\circ} \mathrm{C}^{-1}\right)$, followed by summer $\left(-0.4 \mathrm{~g} \mathrm{~m}^{-2}{ }^{\circ} \mathrm{C}^{-1}\right)$, and it was lowest in the fall $\left(-0.1 \mathrm{~g} \mathrm{~m}^{-2}{ }^{\circ} \mathrm{C}^{-1}\right.$; Fig. 4b). Likewise, in 2015, the absolute reduction in the growth rate in the drought-treated plots was largest across the six grass species and cultivars in spring $\left(-0.2 \mathrm{~g} \mathrm{~m}^{-2}{ }^{\circ} \mathrm{C}^{-1}\right)$, but slightly lower in summer $\left(-0.1 \mathrm{~g} \mathrm{~m}^{-2}{ }^{\circ} \mathrm{C}^{-1}\right)$ and fall $\left(-0.1 \mathrm{~g} \mathrm{~m}^{-2}{ }^{\circ} \mathrm{C}^{-1}\right)$.

The average standing root biomass across four of the grasses was not significantly affected by any of the drought treatments of 2014 (Fig. 6; Table A1; treatment $p=0.572$, season $\times$ treatment $p=0.825)$.

\subsection{Seasonality of post-drought recovery}

When compared to corresponding controls, relative and absolute changes in temperature-weighted growth rates after drought release showed positive treatment effects in 2014 (Fig. 7; Table 4). Across all six grass species and cultivars, the relative increases in post-drought growth rates were $41 \%$ after the spring drought treatment, $31 \%$ after the summer drought treatment and $53 \%$ after the fall drought treatment and did not differ among the seasons (Table 4; season $\times$ treatment $p=0.180$ ). In 2015, the relative increases in post-drought growth rates were $5 \%$ after the spring drought treatment, $15 \%$ after the summer drought treatment and $52 \%$ after the fall drought treatment and did differ among the seasons (Table 4; season $\times$ treatment $p<0.001$ ). Increased relative and absolute growth rates were also observed in the first harvest in 2015 and 2016 for all the plots that had received a drought treatment in 2014 and 2015, respectively (Fig. 4). In this first harvest of 2015, relative growth rate increases were $110 \%$ after the spring, $36 \%$ after the summer and $53 \%$ after the fall drought treatments of 2014. In the first harvest of 2016 , relative growth rate increases were $10 \%$ after the spring, $31 \%$ after the summer and $51 \%$ after the fall drought treatments of 2015.

When compared across the different grass species and cultivars, the only grass that tended to have a weak recovery (lower or no increase in growth rate during post-drought) was LM (Fig. 7), but there was no significant difference among the grass species and cultivars (Table 4; treatment $\times$ grass $p=0.517)$. In 2015, LM again showed the weakest recovery of all the grasses after all drought treatments, with the effect being significant (Table 4; treatment $\times$ grass $p<0.001$ ).

Root dry weight of the treatment plants generally showed no alterations in growth compared to the control (Fig. 6; Table A1; treatment $p=0.553$ ). 

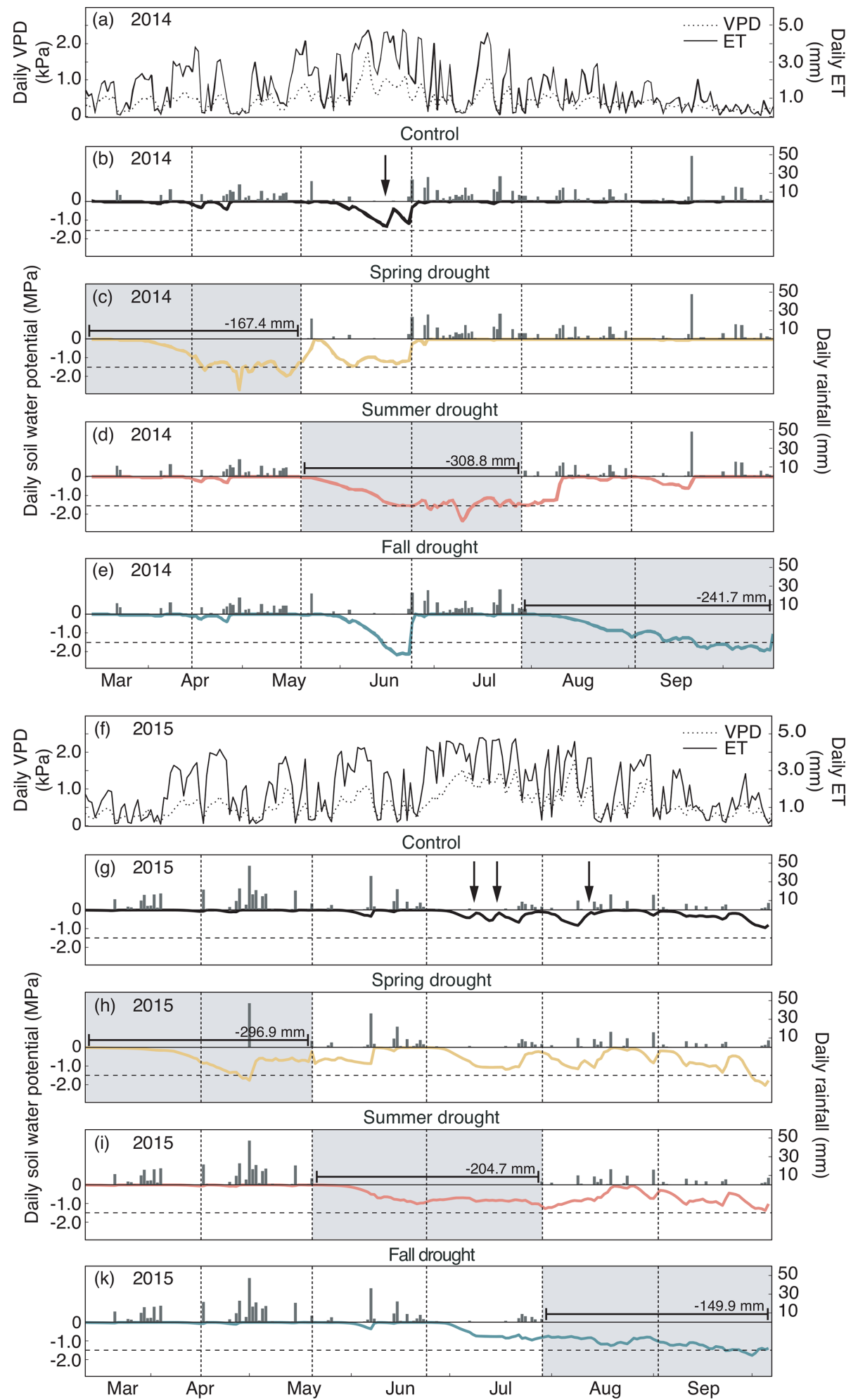

Figure 2. (a, f) Daily evapotranspiration (ET) and vapor pressure deficit (VPD). (b-e, g-k) Daily rainfall and soil water potential ( $\left.\Psi_{\text {Soil }}\right)$ in $10 \mathrm{~cm}$ depth over the growing seasons $2014(\mathbf{a}-\mathbf{e})$ and $2015(\mathbf{f}-\mathbf{k})$ for the control and drought treatment (sensors per treatment $-n=8$ ). Gray shading represents the experimental drought when rainfall was excluded. Dashed horizontal line shows the permanent wilting point $\left(\Psi_{\text {Soil }}=-1.5 \mathrm{MPa}\right)$. Dashed vertical lines represent the dates of the harvest. Arrows indicate the watering events (in control plots only). 
Table 2. (a) Median of soil water potential (MPa) and (b) average air temperature (in ${ }^{\circ} \mathrm{C}$ ) during the two growth periods of the drought treatments, the two post-drought growth periods and the corresponding periods of the rain-fed control. Post-drought values of soil water potential and average air temperature are not displayed (n.d.), as calculating these values for the long winter period between the end of the fall treatment and the spring harvests has little meaning.

\begin{tabular}{|c|c|c|c|c|c|c|c|}
\hline \multirow[t]{2}{*}{ (a) } & \multirow[t]{2}{*}{ Growth period } & \multicolumn{3}{|c|}{ Control } & \multicolumn{3}{|c|}{ Treatment } \\
\hline & & Spring & Summer & Fall & Spring & Summer & Fall \\
\hline & 2014 & \multicolumn{6}{|c|}{$\mathrm{MPa}$} \\
\hline & First drought & -0.03 & -0.41 & -0.01 & -0.09 & -0.72 & -0.73 \\
\hline & Second drought & -0.01 & -0.01 & -0.01 & -1.44 & -1.44 & -1.61 \\
\hline & First post-drought & -0.41 & -0.01 & n.d. & -1.1 & -0.05 & n.d. \\
\hline & Second post-drought & -0.01 & -0.01 & n.d. & -0.01 & -0.02 & n.d. \\
\hline & 2015 & \multicolumn{6}{|c|}{$\mathrm{MPa}$} \\
\hline & First drought & -0.01 & -0.02 & -0.14 & -0.08 & -0.45 & -0.85 \\
\hline & Second drought & -0.01 & -0.25 & -0.34 & -0.77 & -0.83 & -1.34 \\
\hline & First post-drought & -0.02 & -0.14 & n.d. & -0.57 & -0.73 & n.d. \\
\hline & Second post-drought & -0.25 & -0.34 & n.d. & -0.7 & -0.88 & n.d. \\
\hline \multirow[t]{12}{*}{ (b) } & Growth period & & Control & & & Treatment & \\
\hline & & Spring & Summer & Fall & Spring & Summer & Fall \\
\hline & 2014 & \multicolumn{6}{|c|}{${ }^{\circ} \mathrm{C}$} \\
\hline & First drought & 10.3 & 18.0 & 16.6 & 11.0 & 19.0 & 17.3 \\
\hline & Second drought & 10.9 & 18.0 & 15.2 & 11.5 & 18.7 & 15.8 \\
\hline & First post-drought & 18.0 & 16.6 & n.d. & 18.0 & 16.6 & n.d. \\
\hline & Second post-drought & 18.0 & 15.2 & n.d. & 18.0 & 15.2 & n.d. \\
\hline & 2015 & \multicolumn{6}{|c|}{${ }^{\circ} \mathrm{C}$} \\
\hline & First drought & 7.1 & 16.2 & 20.3 & 7.6 & 16.9 & 20.5 \\
\hline & Second drought & 13.3 & 22.7 & 13.0 & 14.4 & 23.7 & 13.5 \\
\hline & First post-drought & 16.2 & 20.3 & n.d. & 16.2 & 20.3 & n.d. \\
\hline & Second post-drought & 22.7 & 13.0 & n.d. & 22.7 & 13 & n.d. \\
\hline
\end{tabular}
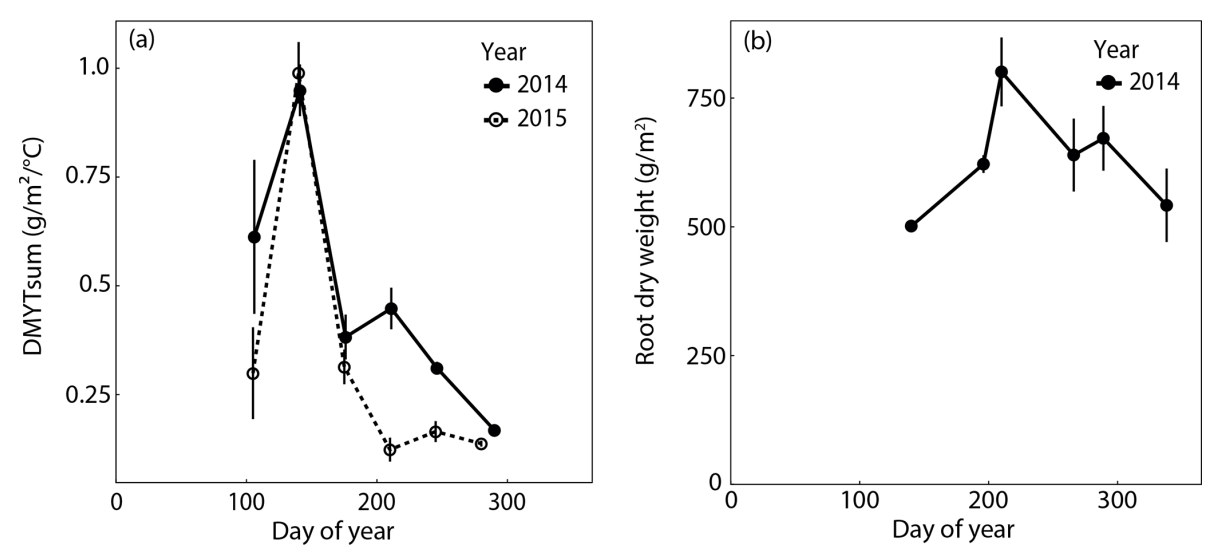

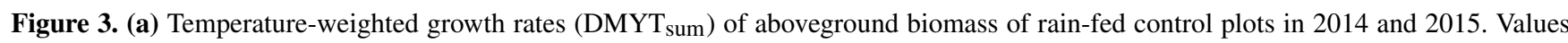
displayed are the means across the six investigated grass species and cultivars $(n=6 ; \pm \mathrm{SE})$. (b) Belowground biomass of rain-fed control plots in 2014. Values displayed are the means across the four grasses, namely L. perenne early (LPe) and late (LPl) flowering and $D$. glomerata early (DGe) and late (DGl) flowering $(n=4 ; \pm \mathrm{SE})$. 

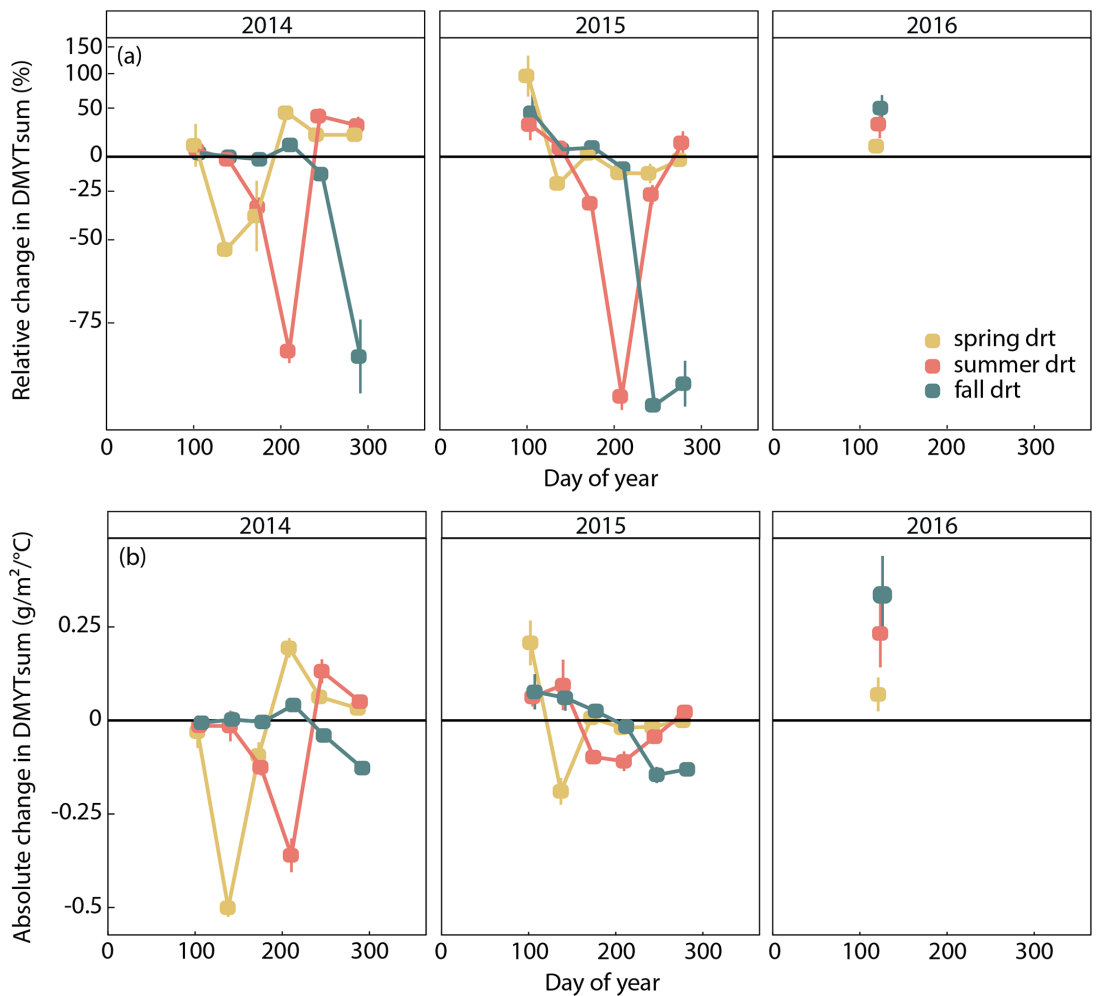

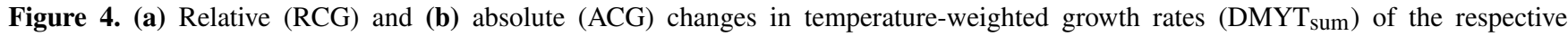
drought (drt) treatment compared to the control (ctr) for 2014, 2015 and 2016. Values shown are the means across all six investigated grass species and cultivars $(n=6 ; \pm \mathrm{SE})$. Values below the horizontal black line indicate reduced growth compared to the control. Values above the line indicate an increase in growth. RCG - 100 $\left.\left(\mathrm{DMYT}_{\text {sum }}(\mathrm{drt}) / \mathrm{DMYT}_{\mathrm{sum}}(\mathrm{ctr})\right)-1\right)$; displayed on the log scale; $\mathrm{ACG}=\mathrm{DMYT}_{\text {sum }}(\mathrm{drt})-\mathrm{DMYT}_{\text {sum }}(\mathrm{ctr})$.

Table 3. Summary of analysis for the effects of season, drought treatment, grass species and cultivars (grass) and their interactions on

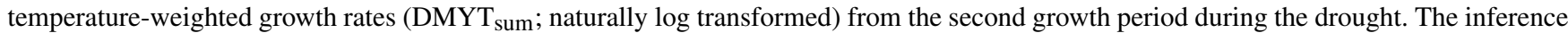
( $F$ and $p$ values) refers to the fixed effects of the linear mixed model. $\mathrm{d} f_{\text {num }}-$ degrees of freedom term; $\mathrm{d} f_{\text {den }}-\operatorname{degrees}$ of freedom of error.

\begin{tabular}{lrrrr|rr}
\hline & & \multicolumn{2}{c}{2014} & \multicolumn{2}{c}{2015} \\
\cline { 4 - 7 } Effect & & & & & \\
& $\mathrm{d} f_{\text {num }}$ & $\mathrm{d} f_{\text {den }}$ & $F$ value & & $F$ value & $p$ \\
\hline Season (spring, summer and fall) & 2 & 36 & 1051.1 & $<0.001$ & 2655.3 & $<0.001$ \\
Treatment (control vs. drought) & 1 & 72 & 341.9 & $<0.001$ & 642.9 & $<0.001$ \\
Grass & 5 & 72 & 9.4 & $<0.001$ & 14.2 & $<0.001$ \\
Season $\times$ treatment & 2 & 72 & 25.9 & $<0.001$ & 366.2 & $<0.001$ \\
Season $\times$ grass & 10 & 36 & 6.8 & $<0.001$ & 10.3 & $<0.001$ \\
Treatment $\times$ grass & 5 & 72 & 2.9 & 0.018 & 2.0 & 0.094 \\
Season $\times$ treatment $\times$ grass & 10 & 72 & 3.3 & 0.001 & 3.4 & 0.001 \\
\hline Marginal $R^{2}$ & & & 0.901 & & 0.965 & \\
Conditional $R^{2}$ & & & 0.917 & & 0.967 & \\
\hline
\end{tabular}

\subsection{Effects of seasonal drought on annual biomass production}

The cumulative annual aboveground biomass production (annual ANPP) of the controls averaged across all six grass species and cultivars differed strongly between the 2 years
(Fig. 8a), with $2014\left(1303 \mathrm{~g} \mathrm{~m}^{-2} \mathrm{a}^{-1}\right)$ being $37 \%$ more productive than $2015\left(949 \mathrm{~g} \mathrm{~m}^{-2} \mathrm{a}^{-1}\right)$. The strong reduction in biomass production in 2015 was probably related to the naturally occurring lack of rain in summer and fall (Fig. 2). But, because the control was irrigated when strong stress occurred, this cannot explain the whole extent. This is evi- 
Table 4. Summary of analysis for the effects of season, drought treatment, grass species and cultivars (grass) and their interactions on temperature-weighted growth rates $\left(\mathrm{DMYT}_{\text {sum }}\right.$; naturally $\log$ transformed) from the second post-drought growth period. See Table 3 for additional explanations.

\begin{tabular}{lrrrr|rr}
\hline & & & \multicolumn{2}{c|}{2014} & \multicolumn{2}{c}{2015} \\
\cline { 5 - 7 } Effect & & & & & \\
& $\mathrm{d} f_{\text {num }}$ & $\mathrm{d} f_{\text {den }}$ & $F$ value & & $F$ value & $p$ \\
\hline Season (spring, summer and fall) & 2 & 36 & 783.4 & $<0.001$ & 1428.6 & $<0.001$ \\
Treatment (control vs. drought) & 1 & 72 & 63.5 & $<0.001$ & 25.5 & $<0.001$ \\
Grass & 5 & 72 & 18.4 & $<0.001$ & 39.4 & $<0.001$ \\
Season $\times$ treatment & 2 & 72 & 1.8 & 0.180 & 16.6 & $<0.001$ \\
Season $\times$ grass & 10 & 36 & 15.7 & $<0.001$ & 9.6 & $<0.001$ \\
Treatment $\times$ grass & 5 & 72 & 0.9 & 0.517 & 6.4 & $<0.001$ \\
Season $\times$ treatment $\times$ grass & 10 & 72 & 2.2 & 0.025 & 0.8 & 0.621 \\
\hline Marginal $R^{2}$ & & & 0.810 & & 0.944 & \\
Conditional $R^{2}$ & & & 0.866 & & 0.946 & \\
\hline
\end{tabular}
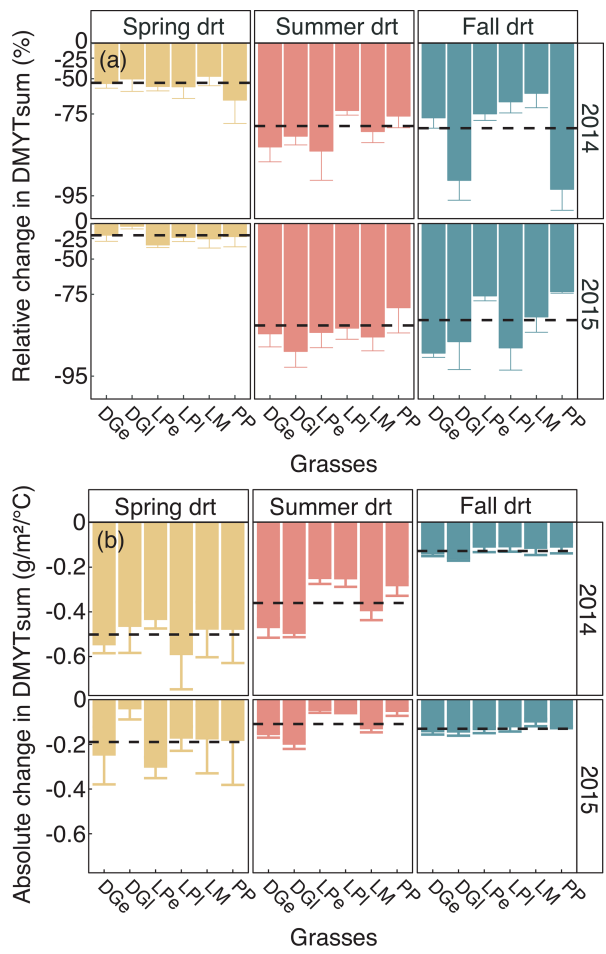

Figure 5. (a) Relative (RCG) and (b) absolute (ACG) changes in temperature-weighted growth rates (DMYT $\mathrm{Dum}_{\text {sum }}$ ) for the second growth period (weeks 6 to 10) of the respective drought (drt) treatment for 2014 and 2015 for the individual grasses. Values shown are means of four replicates per species and cultivar $(n=4 ; \pm \mathrm{SE})$. Dashed black lines represent the means across all grasses. See Fig. 4 for additional explanations. The corresponding statistical analyses are shown in Table A1 in the Appendix.

dent from the two spring growth periods being equally productive in the unsheltered plots (control, summer and fall drought) in 2015 and in 2014 (Fig. 8). The annual ANPP of the treatments was significantly different from the control in
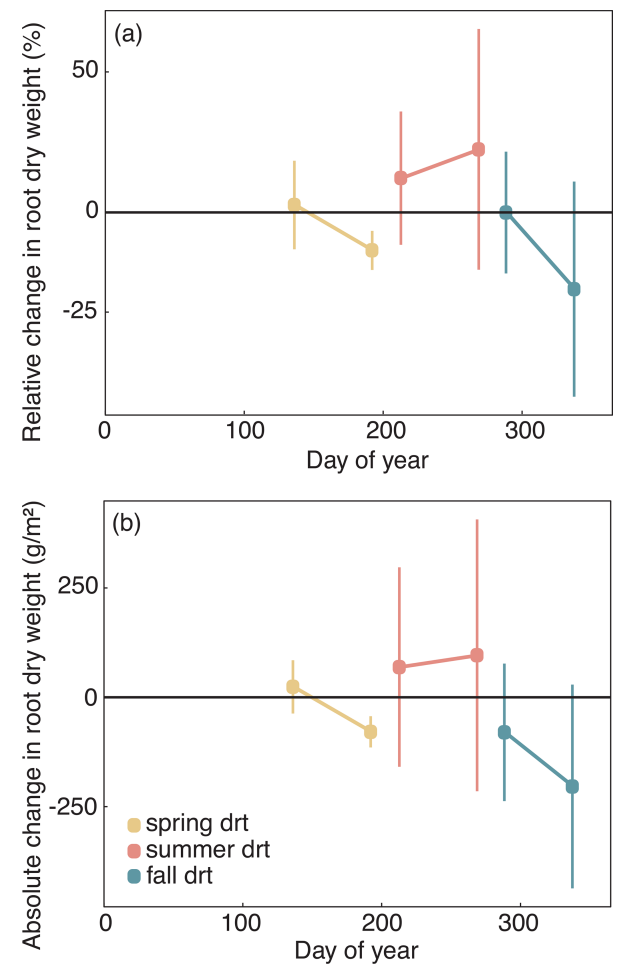

Figure 6. (a) Relative and (b) absolute changes in root dry matter at the end of each drought treatment and after 6 to 8 weeks after drought release in 2014. Values shown are means of four grasses of L. perenne ( $\mathrm{LPe}$ and $\mathrm{LPl})$ and $D$. glomerata (DGe and $\mathrm{DGl})$, each in four replicates $(n=4 ; \pm \mathrm{SE})$.

both years (Table A2; season treatment $p<0.001$ for 2014 and $p=0.007$ for 2015). In 2014, the largest drought effect on the annual ANPP across all grasses resulted from the summer treatment, which reduced productivity significantly by $-14 \%\left(185 \mathrm{~g} \mathrm{~m}^{-2}\right)$ compared to the control (Fig. 8). Spring and fall drought treatments in 2014 resulted in a non- 

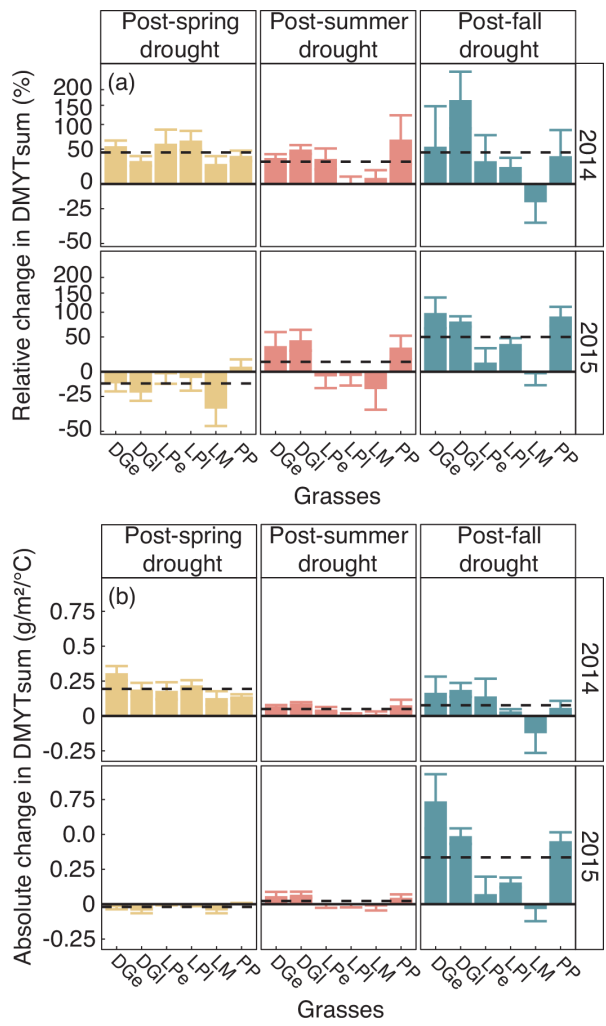

Figure 7. (a) Relative (RCG) and (b) absolute (ACG) changes in temperature-weighted growth rates $\left(\mathrm{DMYT}_{\text {sum }}\right)$ for the second post-drought growth period (weeks 6 to 10) in 2014 and 2015 after the respective drought (drt) treatment for the individual grasses. Values shown are the means of four replicates $(n=4 ; \pm$ SE). Postdrought growth period of the fall drought treatment is the first growth period of the following year. See Fig. 4 for additional explanations. The corresponding statistical analyses are shown in Table A1 in the Appendix.

significant $-4 \%\left(-53 \mathrm{~g} \mathrm{~m}^{-2}\right)$ and $-6 \%\left(-74 \mathrm{~g} \mathrm{~m}^{-2}\right)$ reduction in annual ANPP across all grass species and cultivars, respectively. In 2015, drought treatments in the summer and fall significantly caused a $-10 \%$ and $-11 \%$ reduction in annual ANPP across all grasses ( -97 and $\left.-105 \mathrm{~g} \mathrm{~m}^{-2}\right)$, respectively, while the spring drought treatment reduced annual ANPP across all grasses by only $-4 \%\left(-34 \mathrm{~g} \mathrm{~m}^{-2}\right)$, which was not significant (Fig. 8).

\section{Discussion}

In our study, we experimentally assessed if the drought resistance and recovery of six different temperate perennial $\mathrm{C}_{3}$ grass species and cultivars varies throughout the growing season and if the timing of a drought event has an influence on drought-induced reductions in the annual ANPP of these grasses. All six temperate grass species and cultivars showed a clear seasonal pattern of drought resistance in both years. The drought-induced reduction in growth was smaller

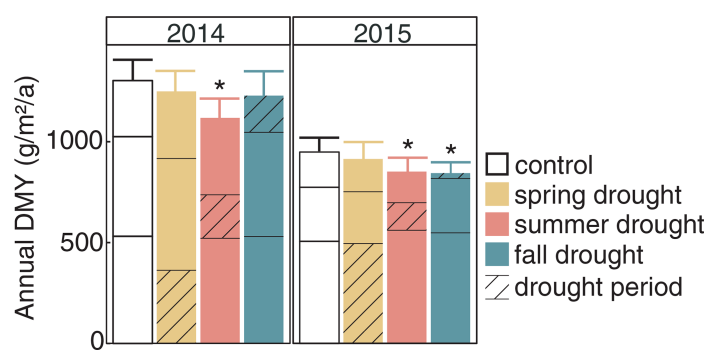

Figure 8. Annual ANPP under rain-fed control and under the three seasonal drought treatments in the years 2014 and 2015. Values shown are means across all six investigated grass species and cultivars $(n=6 ; \pm \mathrm{SE})$. Bars are stacked according to growth in spring (bottom part), summer and fall (top part). Significant differences to the control are marked with an asterisk $(p<0.05)$. The corresponding statistical analyses are shown in Table A2 in the Appendix.

under spring drought $(-20 \%$ and $-51 \%$ for the two years when averaged across the six grasses) than under summer and fall droughts (between $-77 \%$ and $-87 \%$ ). Thus, the investigated grasslands were more resistant to drought in the spring, when the productivity of temperate grasses is generally the highest, and they were least resistant in summer and fall, when their productivity is much lower. This pattern seems to be robust as it occurred in 2 years with strongly differing weather conditions. A second main result was that the examined grasslands did not show any negative legacy effects such as a prolonged suppression of growth after rewetting following the end of the drought treatments. In contrast, after the release from drought, temperature-weighted growth rates of the grasses in the treatment plots surprisingly outperformed the growth rates of the grasses in the controls for extended periods of time. This suggests a high recovery potential of all six grasses that we investigated. As a consequence of the high recovery, the seasonal drought treatments resulted in only moderate drought-induced reductions in annual ANPP between $-4 \%$ to $-14 \%$ - despite the strong immediate effects of drought - and no clear effects of the timing of drought on annual ANPP were detected. With this our study shows (i) that the resistance of growth rates in different grasses to drought varies throughout the growing season and is increased during the reproductive phenological stage when growth rates in the control were highest, (ii) that positive legacy effects of drought on plant productivity indicate a high recovery potential of temperate $\mathrm{C}_{3}$ grasses throughout the entire growing season and (iii) that the high recovery can compensate, to a significant extent, for immediate seasonal drought effects on productivity, resulting in total annual ANPP that is only marginally reduced in the drought-treated plots compared to the controls. 


\subsection{Differences in the meteorological conditions between the 2 years}

While the first experimental year (2014) was characterized by more or less normal meteorological and, thus, growth conditions, the summer and fall of 2015 were exceptionally dry in all of central Europe (Dietrich et al., 2018; Orth et al., 2016). The lack of precipitation in the second half of the 2015 growing season, i.e., between the third harvest in June and the last harvest in October (Fig. 2), was of importance for our experiment, especially for the response of the treatments during the recovery phase after the removal of the shelters. In this period, the amount of rainfall was only $153 \mathrm{~mm}$ in 2015, while it was $405 \mathrm{~mm}$ in 2014. Thus, positive legacy effects directly following drought treatments were much smaller or absent following the spring and summer treatments in 2015 due to a missing rewetting (Figs. 2, 4 and 7).

Intense rains between the first and second harvest of the year 2015 caused some water flow into the treatments. This resulted in a partial reduction in drought stress in the treatment plots (Fig. 2h). Yet, the median of the soil water potential was still clearly reduced in the treatment plots compared to the control and, consequently, we observed a reduction in growth rates in the second spring harvest in 2015 despite this event (Figs. 4 and 5). We therefore conclude that the partial reduction in drought stress did weaken the immediate drought response during the growth period concerned, but that this does not question the overall drought responses of the grasslands that we report here. This is especially evident from the drought stress during weeks 6 to 10 being of comparable severity (Table 2).

\subsection{Grasses were most resistant to drought in spring - the most productive phenological stage}

Previous studies have indicated that the timing of drought is relevant for the reduction of annual ANPP of ecosystems (Bates et al., 2006; Denton et al., 2017; La Pierre et al., 2011; Nippert et al., 2006). It has been argued that the variable drought sensitivity of ecosystems throughout the growing season could be linked to different phenological stages of dominant plant species, where plants in reproductive stages and periods of high growth are particularly susceptible to drought (Bates et al., 2006; Craine et al., 2012; Dietrich and Smith, 2016; Heitschmidt and Vermeire, 2006; O'Toole, 1982). We found, however, that relative reductions in temperature-weighted growth rates were lowest in the spring treatments in 2014 and 2015 compared to the summer and fall treatments. The highest resistance of plant growth rates to drought occurred, thus, when the plants showed the highest growth rates in the control (Fig. 3) and when the investigated grasses were in their reproductive stages. This pattern was robust as it occurred in both years, even although the years differed strongly in terms of their weather conditions. With this, our findings are in contrast to previous stud- ies that have suggested temperate grasslands and crops are particularly susceptible to drought early in the growing season when their growth rates are the highest and plants are in reproductive stages (Bates et al., 2006; Craine et al., 2012; Dietrich and Smith, 2016; Heitschmidt and Vermeire, 2006; Jongen et al., 2011; O'Toole, 1982; Robertson et al., 2009). Our study does support, however, the findings of El Hafid et al. (1998) and Simane et al. (1993), who detected that spring droughts have the least impact on the annual productivity of wheat. Importantly, most of the previous studies that have reported on the effects of drought timing on grasslands or other ecosystems report the effects on annual ANPP but have not differentiated between the immediate effects and legacy effects of drought events as we did in our study. As drought impacts on annual ANPP combine immediate and post-drought legacy effects, it is difficult to directly compare the results we present here to variable seasonal drought resistance of temperate $\mathrm{C}_{3}$ grasses to previous work reporting the influence of drought timing on annual ANPP.

One possibility for the higher drought resistance of grasses during spring is that grasses invest more resources towards the stress resistance of their tissue in this part of the growing season when they have not only the largest growth rates but also reproduce. Such a resource allocation strategy could allow drought-stressed grasses to remain physiologically active in this critical part of the growing season. Osmotic adjustment is one mechanism that reduces the effects of drought on the physiological performance of the plant (Sanders and Arndt, 2012). This is achieved through the active accumulation of organic and inorganic solutes within the plant cell. Thus, osmotic potential increases, and the plant can withstand more negative water potentials in the cell while maintaining its hydraulic integrity (Sánchez et al., 1998). Santamaria et al. (1990) found that early and late flowering cultivars of Sorghum bicolor L. developed a different pattern of osmotic adjustment (continuous increase in osmotic adjustment vs. first increase and later decrease in osmotic adjustment), hinting that drought tolerance may vary among seasons. In a companion paper, we report the physiological data for the six grasses from the same experiment. We show that. at a given soil water potential, foliar water potentials were less negative and stomatal conductance was higher in plants that were drought stressed in the spring compared to plants that were drought stressed in the summer or fall. This suggests that, for a given drought level, grasses remain physiologically more active in the spring than in the summer or fall. The exact physiological mechanisms that explain the higher drought resistance of the investigated grasslands in the spring and their higher drought susceptibility in the summer and fall remain as yet unknown and require further detailed ecophysiological and biochemical assessments.

An alternative explanation for different immediate drought effects on growth rates throughout the growing season are different experimentally induced drought severities throughout a growing season. This could be by either residual 
moisture from winter dampening the experimentally induced drought more in the spring than in the summer or fall. Alternatively, higher evaporative demand of the atmosphere in the summer compared to the spring or fall could have enhanced experimentally induced drought effects in the summer. De Boeck et al. (2011) explain, for example, the higher drought susceptibility of growth in three herbs in the summer compared to spring by a higher evaporative demand of the atmosphere in the summer compared to spring or fall. In our study, however, soil water potential data indicate that 10 weeks of drought treatment resulted in mostly equal water depletion and stress levels in spring, summer and fall (Fig. 2; Table 2). In addition, we found only small differences in median VPD between the spring, summer and fall drought treatment period (Fig. 2). This suggests that stronger drought stress in summer and fall compared to spring alone cannot explain the different resistances of plant growth to drought throughout the growing season. Along these lines, Denton et al. (2017), who performed a similar experiment as we report here but in $\mathrm{a} \mathrm{C}_{4}$ grassland in North America, also did not find that these seasonal differences in the experimentally induced drought severity are the reason for variable drought effects on the growth rates throughout the growing season.

\subsection{No increased root biomass in the top soil layer}

In the entire experiment, root biomass did not generally increase under drought (Table A1) and only increased in one of the investigated grasses (DGe) in one (summer) of the three treatments. This confirms the findings of Byrne et al. (2013), Denton et al. (2017) and Gill et al. (2002), who did not find any changes in belowground biomass in response to drought. In a similar setting, Gilgen and Buchmann (2009) found no changes in belowground biomass to simulated summer drought in three different temperate grassland sites (from lowland to alpine grassland). While Denton et al. (2017) ascribe the missing drought response in belowground biomass to modest precipitation alterations in their experiment, we can exclude this factor in our experiment since the soil water potential under drought was significantly reduced compared to the soil water potential in the controls in every season. Contrary to our finding, several studies have shown that drought can maintain or increase root growth while inhibiting shoot growth (Davies and Zhang, 1991; Hofer et al., 2017a; Saab et al., 1990). In an experiment by Jupp and Newman (1987), L. perenne increased lateral root growth under low $\Psi_{\text {Soil }}$, indicating an increased investment in root growth under water limited conditions. In our experiment, the $L$. perenne grasses did not show a trend towards increased investment in root growth, neither during drought nor after drought release, contradicting the results of Jupp and Newman (1987). Such differences in the response of root biomass in different studies, as described above, may derive from the soil layer that was investigated. Hofer et al. (2017a) have shown that the response of root growth into ingrowth bags depended on the soil depth; root growth of $L$. perenne decreased in the top soil layer $(0-10 \mathrm{~cm})$ but increased in deeper soil layers of $10-30 \mathrm{~cm}$. Thus, the superficial root sampling $(0-14 \mathrm{~cm})$ in our experiment might mask increased root growth in deeper soil layers.

\subsection{Positive legacy effects of drought periods}

Several previous studies have suggested that drought events can lead to negative legacy effects on the productivity of ecosystems (De Boeck et al., 2018; Petrie et al., 2018; Reichmann et al., 2013; Sala et al., 2012). We found, however, that the growth rates of previously drought-stressed plots were significantly larger than in the corresponding control plots after rewetting, indicating not only a high recovery potential of the investigated grasses but even positive legacy effects (Figs. 4 and 7). Interestingly, we did not only observe growth rates that were larger in the treatment plots than in the control plots immediately after the drought release, but we observed larger growth rates in all treatment plots compared to the control plots, even in the first harvests of the following growing season (Fig. 4). This pattern was consistent for both years of the experiment. Bloor and Bardgett (2012) and also Denton et al. (2017) found that drought events promote soil fertility and nutrient retention following drought release. Likewise, Gordon et al. (2008) found an increase in microbial activity after a rewetting event, possibly leading to a rapid and sudden influx of plant-available nutrients in the soil (Mackie et al., 2018; Schimel and Bennett, 2004; Van Sundert et al., 2020). Hofer et al. (2017a) also attributed growth increases relative to control plots in post-drought periods to nitrogen availability in the soil, and Karlowsky et al. (2018) found evidence that interactions between plants and microbes increase plant nitrogen uptake in grasslands after rewetting events. It could, thus, be that the enhanced productivity in the treatment plots following drought release is the result of increased microbial activity leading to enhanced nitrogen availability and/or changes in resource limitation following drought release as suggested by Seastedt and Knapp (1993) in their transient maxima hypothesis.

We applied nitrogen fertilizer in our experiment to each plot after each harvest, also at the beginning and in the middle of a drought treatment. Since we applied the fertilizer in form of water-soluble pellets, it is possible that precipitation exclusion prevented dissolution and, thus, nitrogen fertilizer pellets could have accumulated in the drought-treated plots during the treatment phase. The rewetting of the soil could have resulted in a massive release of nitrogen fertilizer from these pellets so that plant growth rates in formerly droughtstressed plots were stimulated by the release of this fertilizer and were thus larger than those of the control plots. However, Hofer et al. (2017a) observed strongly increased $\mathrm{N}$ availability and plant growth rates after drought release not only in plots that received mineral fertilizer during the drought treatment period, but also in plots that did not receive any $\mathrm{N}$ fertil- 
izer during drought. We suggest therefore that the release of accumulated fertilizer nitrogen in the treatment plots might explain some, but not all post-treatment growth responses in the formerly drought treated plots in our study.

Hagedorn et al. (2016) have shown that rewetting events trigger intrinsic processes that lead to a sudden increase of photosynthesis in young beech trees. Moreover, Arend et al. (2016) found a rapid stimulation of photosynthesis immediately after rewetting that continued until the end of the growing season, partly compensating the loss of photosynthetic activity during drought. Hofer et al. (2017b) found an increased root mass and increased water-soluble carbohydrate reserves in the stubbles of drought stressed L. perenne at the end of a drought stress period. Both of which could have contribute to increased growth rates observed in their study once rewetting had occurred. Also, drought-induced shifts in plant phenology could lead to a shift in high productive stages, e.g., leading to peak growth rates not in spring, but in summer (O'Toole and Cruz, 1980). With the data we collected throughout our experiment, we cannot clearly identify the mechanisms behind the strong and consistent post-drought growth increase that extended even into the next growing season. In the end, several biogeochemical and ecophysiological mechanisms might be responsible for the overcompensation of growth following drought release.

\subsection{Grass species and cultivars only slightly differed in drought resistance and recovery}

During the seasonal drought events the six tested grass species and cultivars showed a mostly universal response with only slight and not consistent differences in their growth rate reductions. Post-drought legacy effects differed, however, among the different grasses in the second year. D. glomerata and $P$. pratensis showed a high potential for recovery and overcompensation after drought, while L. multiflorum generally showed the lowest recovery. Wang et al. (2007) found that plant communities consisting of less productive species were more resistant to drought than plant communities consisting of more productive species. The fact that interspecific differences in the responses to the drought stress and to the following rewetted post-drought period in our study were smaller than in other studies may be related to the fact that all six tested grass species and cultivars belong to a relatively narrow functional group of productive fast-growing grasses with high demands for mineral $\mathrm{N}$ in the soil. The availability of mineral $\mathrm{N}$ in the soil was found to be a key factor for the response during as well as after drought for non-leguminous species (Hofer et al., 2017a, b).

\subsection{Small to moderate impact of seasonal drought on annual ANPP}

Although the immediate effects of drought on growth rates were severe in all three seasons in our study, the overall effects on total annual ANPP from $-4 \%$ to $-14 \%$ were only small to moderate compared to drought effects observed in other studies (Gherardi and Sala, 2019; Wilcox et al., 2017; Wu et al., 2011; Fig. 8). We also did not find any consistent effects of the drought timing on annual ANPP, contrary to other studies (Denton et al., 2017; La Pierre et al., 2011; Nippert et al., 2006; Petrie et al., 2018). This is likely a consequence of the small overall drought effects on annual ANPP in our study. The small drought effects on annual ANPP that we report here are in line with Finn et al. (2018) and can be explained by the high recovery of growth rates in the treatment plots following the drought release. This is particularly evident in the spring treatment, where we observed, on the one side, the largest absolute reduction in growth in response to drought but, at the same time, also the strongest recovery after drought, leading to relatively small total drought effects on annual ANPP. Because the fall drought treatment period lasted until the end of the vegetation period, the positive postdrought legacy effects for this treatment were not included in the calculation of annual biomass production. Nevertheless, the fall drought treatment in 2014 did also not strongly affect the annual ANPP. This is because the growth period affected by the fall drought treatment was the least productive part of the growing season and, thus, contributed only a little to the annual productivity.

The overall effect of drought on annual ANPP might also be small compared to other studies because our study was conducted in highly productive grasslands that, according to best practice management, were harvested six times in the growing season. The drought treatments occurred, however, only in two out of these six growth periods throughout the growing season. In addition, the first sheltered growth period generally did not show a reduced growth rate (Fig. 4), as soil water stress in this period was low (Fig. 2; Table 2). With the absence of negative legacy effects, the impact of the immediate drought effect of one single drought-stressed growth period on annual NPP was therefore diluted by the five other harvests of the vegetation period (Finn et al., 2018). While strongly reduced soil water potentials in the sheltered plots occurred only during one regrowth period in 2014 (Fig. 1), the exceptionally dry weather conditions in the second half of the growing season in 2015 resulted in three consecutive regrowth periods with clearly reduced soil water potentials. We suggest that this long-lasting drought was the main reason for the strong yield reduction observed in $2015(-37 \%$ in the control plots) compared to 2014, especially because the yield of spring growth was comparable among the 2 years (Fig. 8; bottom part of the bars).

The majority of studies that have assessed the impact of drought on grassland productivity have either assessed im- 
mediate drought effects, i.e., drought resistance (Bollig and Feller, 2014; Kahmen et al., 2005; Walter et al., 2012; Wang et al., 2007), or the net effects of drought on annual NPP (Gherardi and Sala, 2019; Wilcox et al., 2017; Wu et al., 2011). Our study highlights that it is important to also quantify immediate and post-drought effects - even in the following growing season - if the causes of drought-reduced annual productivity are to be understood.

Effects of drought on the annual ANPP of grasslands have been shown to vary, depending on the severity of the experienced drought (Vicca et al., 2012; Wilcox et al., 2017), ecosystem type (Byrne et al., 2013; Gherardi and Sala, 2019; Sala et al., 2015; Wilcox et al., 2017), the intensity of land use (Vogel et al., 2012; Walter et al., 2012), the plant functional composition (Gherardi and Sala, 2015; Hofer et al., 2016, 2017a; Mackie et al., 2018) or the biodiversity of an ecosystem (Haughey et al., 2018; Isbell et al., 2015; Kahmen et al., 2005; Wagg et al., 2017). Our study shows that the timing of a drought event in the growing season is also crucial for the immediate effects of a drought on grassland productivity. Importantly, however, our study also shows that strong positive legacy effects can occur after rewetting, and that these legacy effects are even important in the spring of the next year. These effects can partially compensate for the strong immediate drought effects and lead to relatively small overall seasonal drought effects on annual ANPP. 


\section{Appendix A}

Table A1. Summary of analysis for the effects of season, drought treatment, grass and their interactions on root biomass in 2014 (root dry weight; naturally log transformed) at the end of each drought treatment (drought) and after 6 to 8 weeks after drought release (recovery). The inference ( $F$ and $p$ values) refers to the fixed effects of the linear mixed model. $\mathrm{d} f_{\text {num }}-$ degrees of freedom term; $\mathrm{d} f_{\text {den }}-\operatorname{degrees}$ of freedom of error.

\begin{tabular}{lrrrr|rr}
\hline & & & \multicolumn{2}{c|}{ Drought } & \multicolumn{2}{c}{ Recovery } \\
\cline { 5 - 8 } Effect & $\mathrm{d} f_{\text {num }}$ & $\mathrm{d} f_{\text {den }}$ & $F$ value & $p$ & $F$ value & $p$ \\
\hline Season (spring, summer and fall) & 2 & 24 & 34.4 & $<0.001$ & 20.8 & $<0.001$ \\
Treatment (control vs. drought) & 1 & 48 & 0.3 & 0.572 & 0.4 & 0.553 \\
Grass & 3 & 48 & 6.5 & $<0.001$ & 8.5 & $<0.001$ \\
Season $\times$ treatment & 2 & 48 & 0.2 & 0.825 & 3.8 & 0.030 \\
Season $\times$ grass & 6 & 24 & 3.9 & 0.007 & 5.2 & 0.002 \\
Treatment $\times$ grass & 3 & 48 & 2.1 & 0.113 & 5.2 & 0.003 \\
Season $\times$ treatment $\times$ grass & 6 & 48 & 1.9 & 0.104 & 4.8 & $<0.001$ \\
\hline Marginal $R^{2}$ & & & 0.486 & & 0.619 & \\
Conditional $R^{2}$ & & & 0.503 & & 0.780 & \\
\hline
\end{tabular}

Table A2. Summary of the analysis for the effects of seasonal treatment, grass and their interaction on cumulative annual aboveground biomass production (i.e., annual ANPP).

\begin{tabular}{lrrr|rr}
\hline & & \multicolumn{2}{c|}{2014} & \multicolumn{2}{c}{2015} \\
\cline { 3 - 6 } Effect & $\mathrm{d} f_{\text {num }}$ & $F$ value & $p$ & $F$ value & $p$ \\
\hline Seasonal treatment & 3 & 9.4 & $<0.001$ & 4.3 & 0.007 \\
Grass & 5 & 64.3 & $<0.001$ & 28.8 & $<0.001$ \\
Seasonal treatment $\times$ grass & 15 & 0.8 & 0.687 & 1.4 & 0.190 \\
Residuals & 72 & & & & \\
\hline Adjusted $R^{2}$ & & 0.781 & & 0.619 & \\
\hline
\end{tabular}


Data availability. Raw data collected in this experiment are available at https://doi.org/10.5281/zenodo.4306840 (Hahn, 2020).

Author contributions. AK and AL planned, designed and supervised the research. $\mathrm{CH}$ and $\mathrm{SEH}$ performed the experiments. $\mathrm{CH}$ and MS analyzed the data; $\mathrm{CH}$ wrote the paper. $\mathrm{AK}, \mathrm{AL}$ and $\mathrm{MS}$ cowrote the paper.

Competing interests. The authors declare that they have no conflict of interest.

Acknowledgements. We thank Cornel Stutz and Rafael Gago, for their technical assistance in the field, and Florian Cueni, for his support with the fieldwork and sample processing. The Federal Office for Meteorology (MeteoSwiss) is kindly acknowledged for providing access to the meteorological data.

Financial support. This research has been supported by the IDP BRIDGES project in the European Union's Seventh Framework Programme (PITN-GA-643 2013; grant no. 608422).

Review statement. This paper was edited by Akihiko Ito and reviewed by two anonymous referees.

\section{References}

Arend, M., Sever, K., Pflug, E., Gessler, A., and Schaub, M.: Seasonal photosynthetic response of European beech to severe summer drought: Limitation, recovery and postdrought stimulation, Agr. Forest Meteorol., 220, 83-89, https://doi.org/10.1016/j.agrformet.2016.01.011, 2016.

Bates, J. D., Svejcar, T., Miller, R. F., and Angell, R. A.: The effects of precipitation timing on sagebrush steppe vegetation, J. Arid Environ., 64, 670-697, https://doi.org/10.1016/j.jaridenv.2005.06.026, 2006.

Bloor, J. M. G. and Bardgett, R. D.: Stability of above-ground and below-ground processes to extreme drought in model grassland ecosystems: Interactions with plant species diversity and soil nitrogen availability, Perspect. Plant Ecol., 14, 193-204, https://doi.org/10.1016/j.ppees.2011.12.001, 2012.

Bollig, C. and Feller, U.: Impacts of drought stress on water relations and carbon assimilation in grassland species at different altitudes, Agr. Ecosyst. Environ., 188, 212-220, https://doi.org/10.1016/j.agee.2014.02.034, 2014.

Byrne, K. M., Lauenroth, W. K., and Adler, P. B.: Contrasting Effects of Precipitation Manipulations on Production in Two Sites within the Central Grassland Region, USA, Ecosystems, 16, 1039-1051, https://doi.org/10.1007/s10021-013-9666-z, 2013.

Craine, J. M., Nippert, J. B., Elmore, A. J., Skibbe, A. M., Hutchinson, S. L., and Brunsell, N. A.: Timing of climate variability and grassland productivity, P. Natl. Acad. Sci. USA, 109, 3401-3405, https://doi.org/10.1073/pnas.1118438109, 2012.
Davies, W. J. and Zhang, J.: Root signals and the regulation of growth and development of plants in drying soil, Annu. Rev. Plant Biol., 42, 55-76, 1991.

De Boeck, H. J., Dreesen, F. E., Janssens, I. A., and Nijs, I.: Wholesystem responses of experimental plant communities to climate extremes imposed in different seasons, New Phytol., 189, 806817, https://doi.org/10.1111/j.1469-8137.2010.03515.x, 2011.

De Boeck, H. J., Hiltbrunner, E., Verlinden, M., Bassin, S., and Zeiter, M.: Legacy Effects of Climate Extremes in Alpine Grassland, Front. Plant Sci., 9, 1586, https://doi.org/10.3389/fpls.2018.01586, 2018.

Denton, E. M., Dietrich, J. D., Smith, M. D., and Knapp, A. K.: Drought timing differentially affects above- and belowground productivity in a mesic grassland, Plant Ecol., 218, 317-328, https://doi.org/10.1007/s11258-016-0690-x, 2017.

Dietrich, J. D. and Smith, M. D.: The effect of timing of growing season drought on flowering of a dominant $\mathrm{C}_{4}$ grass, Oecologia, 181, 391-399, https://doi.org/10.1007/s00442-016-3579-4, 2016.

Dietrich, L., Zweifel, R., and Kahmen, A.: Daily stem diameter variations can predict the canopy water status of mature temperate trees, Tree Physiol., 38, 941-952, https://doi.org/10.1093/treephys/tpy023, 2018.

El Hafid, R., Smith, D. H., Karrou, M., and Samir, K.: Morphological attributes associated with early-season drought tolerance in spring durum wheat in a Mediterranean environment, Euphytica, 101, 273-282, 1998.

Finn, J. A., Suter, M., Haughey, E., Hofer, D., and Lüscher, A.: Greater gains in annual yields from increased plant diversity than losses from experimental drought in two temperate grasslands, Agr. Ecosyst. Environ., 258, 149-153, https://doi.org/10.1016/j.agee.2018.02.014, 2018.

Fuchslueger, L., Bahn, M., Fritz, K., Hasibeder, R., and Richter, A.: Experimental drought reduces the transfer of recently fixed plant carbon to soil microbes and alters the bacterial community composition in a mountain meadow, New Phytol., 201, 916-927, https://doi.org/10.1111/nph.12569, 2014.

Fuchslueger, L., Bahn, M., Hasibeder, R., Kienzl, S., Fritz, K., Schmitt, M., Watzka, M., and Richter, A.: Drought history affects grassland plant and microbial carbon turnover during and after a subsequent drought event, edited by A. Austin, J. Ecol., 104, 1453-1465, https://doi.org/10.1111/1365-2745.12593, 2016.

Gherardi, L. A. and Sala, O. E.: Enhanced interannual precipitation variability increases plant functional diversity that in turn ameliorates negative impact on productivity, Ecol. Lett., 18, 1293-1300, https://doi.org/10.1111/ele.12523, 2015.

Gherardi, L. A. and Sala, O. E.: Effect of interannual precipitation variability on dryland productivity: A global synthesis, Glob. Change Biol., 25, 269-276, https://doi.org/10.1111/gcb.14480, 2019.

Gibson, D. J.: Grasses and grassland ecology, Oxford University Press, Oxford, 2009.

Gilgen, A. K. and Buchmann, N.: Response of temperate grasslands at different altitudes to simulated summer drought differed but scaled with annual precipitation, Biogeosciences, 6, 2525-2539, https://doi.org/10.5194/bg-6-2525-2009, 2009.

Gill, R. A., Kelly, R. H., Parton, W. J., Day, K. A., Jackson, R. B., Morgan, J. A., Scurlock, J. M. O., Tieszen, L. L., Castle, J. V., and Ojima, D. S.: Using simple environmental variables to 
estimate below-ground productivity in grasslands, Global Ecol. Biogeogr., 11, 79-86, 2002.

Gordon, H., Haygarth, P. M., and Bardgett, R. D.: Drying and rewetting effects on soil microbial community composition and nutrient leaching, Soil Biol. Biochem., 40, 302-311, https://doi.org/10.1016/j.soilbio.2007.08.008, 2008.

Grant, K., Kreyling, J., Dienstbach, L. F. H., Beierkuhnlein, C., and Jentsch, A.: Water stress due to increased intra-annual precipitation variability reduced forage yield but raised forage quality of a temperate grassland, Agr. Ecosyst. Environ., 186, 11-22, https://doi.org/10.1016/j.agee.2014.01.013, 2014.

Griffin-Nolan, R. J., Carroll, C. J. W., Denton, E. M., Johnston, M. K., Collins, S. L., Smith, M. D., and Knapp, A. K.: Legacy effects of a regional drought on aboveground net primary production in six central US grasslands, Plant Ecol., 219, 505-515, https://doi.org/10.1007/s11258-018-0813-7, 2018.

Hagedorn, F., Joseph, J., Peter, M., Luster, J., Pritsch, K., Geppert, U., Kerner, R., Molinier, V., Egli, S., Schaub, M., Liu, J.-F., Li, M., Sever, K., Weiler, M., Siegwolf, R. T. W., Gessler, A., and Arend, M.: Recovery of trees from drought depends on belowground sink control, Nat. Plants, 2, 16111, https://doi.org/10.1038/nplants.2016.111, 2016.

Hahn, C.: Timing of drought in the growing season, Zenodo, https://doi.org/10.5281/zenodo.4306840, 2020.

Haughey, E., Suter, M., Hofer, D., Hoekstra, N. J., McElwain, J. C., Lüscher, A., and Finn, J. A.: Higher species richness enhances yield stability in intensively managed grasslands with experimental disturbance, Sci. Rep.-UK, 8, 15047, https://doi.org/10.1038/s41598-018-33262-9, 2018.

Heitschmidt, R. K. and Vermeire, L. T.: Can Abundant Summer Precipitation Counter Losses in Herbage Production Caused by Spring Drought?, Rangeland Ecol. Manag., 59, 392-399, https://doi.org/10.2111/05-164R2.1, 2006.

Hoekstra, N. J., Finn, J. A., Hofer, D., and Lüscher, A.: The effect of drought and interspecific interactions on depth of water uptake in deep- and shallow-rooting grassland species as determined by $\delta^{18} \mathrm{O}$ natural abundance, Biogeosciences, 11, 44934506, https://doi.org/10.5194/bg-11-4493-2014, 2014.

Hofer, D., Suter, M., Haughey, E., Finn, J. A., Hoekstra, N. J., Buchmann, N., and Lüscher, A.: Yield of temperate forage grassland species is either largely resistant or resilient to experimental summer drought, J. Appl. Ecol., 53, 1023-1034, https://doi.org/10.1111/1365-2664.12694, 2016.

Hofer, D., Suter, M., Buchmann, N., and Lüscher, A.: Nitrogen status of functionally different forage species explains resistance to severe drought and post-drought overcompensation, Agr. Ecosyst. Environ., 236, 312-322, https://doi.org/10.1016/j.agee.2016.11.022, 2017a.

Hofer, D., Suter, M., Buchmann, N., and Lüscher, A.: Severe water deficit restricts biomass production of Lolium perenne L. and Trifolium repens $\mathrm{L}$. and causes foliar nitrogen but not carbohydrate limitation, Plant Soil, 421, 367-380, https://doi.org/10.1007/s11104-017-3439-y, 2017b.

Hoover, D. L., Knapp, A. K., and Smith, M. D.: Resistance and resilience of a grassland ecosystem to climate extremes, Ecology, 95, 2646-2656, 2014.

Ingrisch, J. and Bahn, M.: Towards a Comparable Quantification of Resilience, Trends Ecol. Evol., 33, 251-259, https://doi.org/10.1016/j.tree.2018.01.013, 2018.
Isbell, F., Craven, D., Connolly, J., Loreau, M., Schmid, B., Beierkuhnlein, C., Bezemer, T. M., Bonin, C., Bruelheide, H., de Luca, E., Ebeling, A., Griffin, J. N., Guo, Q., Hautier, Y., Hector, A., Jentsch, A., Kreyling, J., Lanta, V., Manning, P., Meyer, S. T., Mori, A. S., Naeem, S., Niklaus, P. A., Polley, H. W., Reich, P. B., Roscher, C., Seabloom, E. W., Smith, M. D., Thakur, M. P., Tilman, D., Tracy, B. F., van der Putten, W. H., van Ruijven, J., Weigelt, A., Weisser, W. W., Wilsey, B., and Eisenhauer, N.: Biodiversity increases the resistance of ecosystem productivity to climate extremes, Nature, 526, 574-577, https://doi.org/10.1038/nature15374, 2015.

Jongen, M., Pereira, J. S., Aires, L. M. I., and Pio, C. A.: The effects of drought and timing of precipitation on the inter-annual variation in ecosystem-atmosphere exchange in a Mediterranean grassland, Agr. Forest Meteorol., 151, 595-606, https://doi.org/10.1016/j.agrformet.2011.01.008, 2011.

Jupp, A. P. and Newman, E. I.: Morphological and anatomical effects of severe drought on the roots of Lolium perenne L., New Phytol., 105, 393-402, 1987.

Kahmen, A., Perner, J., and Buchmann, N.: Diversitydependent productivity in semi-natural grasslands following climate perturbations, Funct. Ecol., 19, 594-601, https://doi.org/10.1111/j.1365-2435.2005.01001.x, 2005.

Karlowsky, S., Augusti, A., Ingrisch, J., Hasibeder, R., Lange, M., Lavorel, S., Bahn, M., and Gleixner, G.: Land use in mountain grasslands alters drought response and recovery of carbon allocation and plant-microbial interactions, J. Ecol., 106, 1230-1243, https://doi.org/10.1111/1365-2745.12910, 2018.

Kreyling, J., Dengler, J., Walter, J., Velev, N., Ugurlu, E., Sopotlieva, D., Ransijn, J., Picon-Cochard, C., Nijs, I., Hernandez, P., Güler, B., von Gillhaussen, P., De Boeck, H. J., Bloor, J. M. G., Berwaers, S., Beierkuhnlein, C., Arfin Khan, M. A. S., Apostolova, I., Altan, Y., Zeiter, M., Wellstein, C., Sternberg, M., Stampfli, A., Campetella, G., Bartha, S., Bahn, M., and Jentsch, A.: Species richness effects on grassland recovery from drought depend on community productivity in a multisite experiment, Ecol. Lett., 20, 1405-1413, https://doi.org/10.1111/ele.12848, 2017.

La Pierre, K. J., Yuan, S., Chang, C. C., Avolio, M. L., Hallett, L. M., Schreck, T., and Smith, M. D.: Explaining temporal variation in above-ground productivity in a mesic grassland: the role of climate and flowering: Flowering, seasonal climate drive ANPP variation, J. Ecol., 99, 1250-1262, https://doi.org/10.1111/j.1365-2745.2011.01844.x, 2011.

Mackie, K. A., Zeiter, M., Bloor, J. M. G., and Stampfli, A.: Plant functional groups mediate drought resistance and recovery in a multisite grassland experiment, J. Ecol., 107, https://doi.org/10.1111/1365-2745.13102, 2018.

Menzi, H., Blum, H., and Nösberger, J.: Relationship between climatic factors and the dry matter production of swards of different composition at two altitudes, Grass Forage Sci., 46, 223-230, 1991.

Nakagawa, S. and Schielzeth, H.: A general and simple method for obtaining $R^{2}$ from generalized linear mixedeffects models, Methods Ecol. Evol., 4(2), 133-142, https://doi.org/10.1111/j.2041-210x.2012.00261.x, 2013.

Nippert, J. B., Knapp, A. K., and Briggs, J. M.: Intra-annual rainfall variability and grassland productivity: can the past predict the 
future?, Plant Ecol., 184, 65-74, https://doi.org/10.1007/s11258005-9052-9, 2006.

O’Brien, M. J., Ong, R., and Reynolds, G.: Intra-annual plasticity of growth mediates drought resilience over multiple years in tropical seedling communities, Glob. Change Biol., 23, 4235-4244, https://doi.org/10.1111/gcb.13658, 2017.

Orth, R., Zscheischler, J., and Seneviratne, S. I.: Record dry summer in 2015 challenges precipitation projections in Central Europe, Sci. Rep.-UK, 6, 28334, https://doi.org/10.1038/srep28334, 2016.

O'Toole, J. C.: Adaptation of Rice to Drought-prone Environments, in: Drought Resistance in Crops With Emphasis on Rice, Paddyfield, Manila, Philippines, 195, 1982.

O'Toole, J. C. and Cruz, R. T.: Response of leaf water potential, stomatal resistance, and leaf rolling to water stress, Plant Physiol., 65, 428-432, 1980.

Paschalis, A., Fatichi, S., Zscheischler, J., Ciais, P., Bahn, M., Boysen, L., Chang, J., De Kauwe, M., Estiarte, M., Goll, D., Hanson, P. J., Harper, A. B., Hou, E., Kigel, J., Knapp, A. K., Larsen, K. S., Li, W., Lienert, S., Luo, Y., Meir, P., Nabel, J. E. M. S., Ogaya, R., Parolari, A. J., Peng, C., Peñuelas, J., Pongratz, J., Rambal, S., Schmidt, I. K., Shi, H., Sternberg, M., Tian, H., Tschumi, E., Ukkola, A., Vicca, S., Viovy, N., Wang, Y., Wang, Z., Williams, K., Wu, D. and Zhu, Q.: Rainfall manipulation experiments as simulated by terrestrial biosphere models: Where do we stand?, Glob. Change Biol., 26, 3336-3355, https://doi.org/10.1111/gcb.15024, 2020.

Petrie, M. D., Peters, D. P. C., Yao, J., Blair, J. M., Burruss, N. D., Collins, S. L., Derner, J. D., Gherardi, L. A., Hendrickson, J. R., Sala, O. E., Starks, P. J., and Steiner, J. L.: Regional grassland productivity responses to precipitation during multiyear above- and below-average rainfall periods, Glob. Change Biol., 24, 1935-1951, https://doi.org/10.1111/gcb.14024, 2018.

Pinheiro, J. C. and Bates, D. M.: Linear mixed-effects models: basic concepts and examples, in: Mixed-Effects Models in S and SPLUS, Springer Science \& Business Media, New York, 3-56, 2000.

Reichmann, L. G., Sala, O. E., and Peters, D. P.: Precipitation legacies in desert grassland primary production occur through previous-year tiller density, Ecology, 94, 435-443, 2013.

Reichstein, M., Bahn, M., Ciais, P., Frank, D., Mahecha, M. D., Seneviratne, S. I., Zscheischler, J., Beer, C., Buchmann, N., Frank, D. C., Papale, D., Rammig, A., Smith, P., Thonicke, K., van der Velde, M., Vicca, S., Walz, A., and Wattenbach, M.: Climate extremes and the carbon cycle, Nature, 500, 287-295, https://doi.org/10.1038/nature12350, 2013.

Robertson, T. R., Bell, C. W., Zak, J. C., and Tissue, D. T.: Precipitation timing and magnitude differentially affect aboveground annual net primary productivity in three perennial species in a Chihuahuan Desert grassland, New Phytol., 181, 230-242, https://doi.org/10.1111/j.1469-8137.2008.02643.x, 2009.

Saab, I. N., Sharp, R. E., Pritchard, J., and Voetberg, G. S.: Increased endogenous abscisic acid maintains primary root growth and inhibits shoot growth of maize seedlings at low water potentials, Plant Physiol., 93, 1329-1336, 1990.

Sala, O. E., Gherardi, L. A., Reichmann, L., Jobbagy, E., and Peters, D.: Legacies of precipitation fluctuations on primary production: theory and data synthesis, Philos. T. R. Soc. B, 367, 3135-3144, https://doi.org/10.1098/rstb.2011.0347, 2012.
Sala, O. E., Gherardi, L. A., and Peters, D. P. C.: Enhanced precipitation variability effects on water losses and ecosystem functioning: differential response of arid and mesic regions, Climatic Change, 131, 213-227, https://doi.org/10.1007/s10584015-1389-z, 2015.

Sánchez, F. J., Manzanares, M., de Andres, E. F., Tenorio, J. L., and Ayerbe, L.: Turgor maintenance, osmotic adjustment and soluble sugar and proline accumulation in 49 pea cultivars in response to water stress, Field Crop. Res., 59, 225-235, 1998.

Sanders, G. J. and Arndt, S. K.: Osmotic adjustment under drought conditions, in: Plant Responses to Drought Stress, edited by: Ricardo, A., 199-229, Springer, Berlin, Heidelberg, 2012.

Santamaria, J. M., Ludlow, M. M., and Fukai, S.: Contribution of osmotic adjustment to grain yield in Sorghum bicolor (L.) Moench under water-limited conditions. I. Water stress before anthesis, Aust. J. Agr. Res., 41, 51-65, 1990.

Schiermeier, Q.: The real holes in climate science: like any other field, research on climate change has some fundamental gaps, although not the ones typically claimed by sceptics, Quirin Schiermeier takes a hard look at some of the biggest problem areas, Nature, 463, 284-287, 2010.

Schimel, J. P. and Bennett, J.: Nitrogen mineralization: challenges of a changing paradigm, Ecology, 85, 591-602, 2004.

Seastedt, T. R. and Knapp, A. K.: Consequences of Nonequilibrium Resource Availability Across Multiple Time Scales: The Transient Maxima Hypothesis, Am. Nat., 141, 621-633, https://doi.org/10.1086/285494, 1993.

Shen, W., Jenerette, G. D., Hui, D., and Scott, R. L.: Precipitation legacy effects on dryland ecosystem carbon fluxes: direction, magnitude and biogeochemical carryovers, Biogeosciences, 13, 425-439, https://doi.org/10.5194/bg-13-425-2016, 2016.

Simane, B., Peacock, J. M., and Struik, P. C.: Differences in developmental plasticity and growth rate among drought-resistant and susceptible cultivars of durum wheat (Triticum turgidum L. var. durum), Plant Soil, 157, 155-166, 1993.

Smith, N. G., Rodgers, V. L., Brzostek, E. R., Kulmatiski, A., Avolio, M. L., Hoover, D. L., Koerner, S. E., Grant, K., Jentsch, A., Fatichi, S., and Niyogi, D.: Toward a better integration of biological data from precipitation manipulation experiments into Earth system models, Rev. Geophys., 52, 412-434, https://doi.org/10.1002/2014RG000458, 2014.

Van Sundert, K., Brune, V., Bahn, M., Deutschmann, M., Hasibeder, R., Nijs, I., and Vicca, S.: Post-drought rewetting triggers substantial $\mathrm{K}$ release and shifts in leaf stoichiometry in managed and abandoned mountain grasslands, Plant Soil, 448, 353-368, https://doi.org/10.1007/s11104-020-04432-4, 2020.

Vicca, S., Gilgen, A. K., Camino Serrano, M., Dreesen, F. E., Dukes, J. S., Estiarte, M., Gray, S. B., Guidolotti, G., Hoeppner, S. S., Leakey, A. D. B., Ogaya, R., Ort, D.R., Ostrogovic, M. Z., Rambal, S., Sardans, J., Schmitt, M., Siebers, M., van der Linden, L., van Straaten, O., and Granier, A.: Urgent need for a common metric to make precipitation manipulation experiments comparable, New Phytol., 195, 518-522, 2012.

Vogel, A., Scherer-Lorenzen, M., and Weigelt, A.: Grassland Resistance and Resilience after Drought Depends on Management Intensity and Species Richness, PLoS ONE, 7, e36992, https://doi.org/10.1371/journal.pone.0036992, 2012.

Voigtländer, G. and Boeker, P.: Grünlandwirtschaft und Futterbau, Ulmer, Stuttgart, 1987. 
Voisin, A.: Grass productivity, Island Press, Washington, DC, 1988. Wagg, C., O’Brien, M. J., Vogel, A., Scherer-Lorenzen, M., Eisenhauer, N., Schmid, B., and Weigelt, A.: Plant diversity maintains long-term ecosystem productivity under frequent drought by increasing short-term variation, Ecology, 98, 2952-2961, https://doi.org/10.1002/ecy.2003, 2017.

Walter, J., Grant, K., Beierkuhnlein, C., Kreyling, J., Weber, M., and Jentsch, A.: Increased rainfall variability reduces biomass and forage quality of temperate grassland largely independent of mowing frequency, Agr. Ecosyst. Environ., 148, 1-10, https://doi.org/10.1016/j.agee.2011.11.015, 2012.

Wang, Y., Yu, S., and Wang, J.: Biomass-dependent susceptibility to drought in experimental grassland communities, Ecol. Lett., 10, 401-410, https://doi.org/10.1111/j.1461-0248.2007.01031.x, 2007.
Wilcox, K. R., Shi, Z., Gherardi, L. A., Lemoine, N. P., Koerner, S. E., Hoover, D. L., Bork, E., Byrne, K. M., Cahill, J., Collins, S. L., Evans, S., Gilgen, A. K., Holub, P., Jiang, L., Knapp, A. K., LeCain, D., Liang, J., Garcia-Palacios, P., Peñuelas, J., Pockman, W. T., Smith, M. D., Sun, S., White, S. R., Yahdjian, L., Zhu, K., and Luo, Y.: Asymmetric responses of primary productivity to precipitation extremes: A synthesis of grassland precipitation manipulation experiments, Glob. Change Biol., 23, 4376-4385, https://doi.org/10.1111/gcb.13706, 2017.

Wu, Z., Dijkstra, P., Koch, G. W., Peñuelas, J., and Hungate, B. A.: Responses of terrestrial ecosystems to temperature and precipitation change: a meta-analysis of experimental manipulation: meta-analysis of experimental manipulation, Glob. Change Biol., 17, 927-942, https://doi.org/10.1111/j.1365-2486.2010.02302.x, 2011.

Yahdjian, L. and Sala, O. E.: Vegetation structure constrains primary production response to water availability in the Patagonian steppe, Ecology, 87, 952-962, 2006. 